\title{
Increased aerosol content in the atmosphere over Ukraine during summer 2010
}

\author{
Evgenia Galytska $^{1}$, Vassyl Danylevsky ${ }^{2}$, René Hommel ${ }^{1, a}$, and John P. Burrows ${ }^{1}$ \\ ${ }^{1}$ Institute of Environmental Physics, University of Bremen, Bremen, Germany \\ ${ }^{2}$ Taras Shevchenko National University, Kyiv, Ukraine \\ a now at: Hommel \& Graf Environmental, Hamburg, Germany
}

Correspondence: Evgenia Galytska (egalytska@iup.physik.uni-bremen.de)

Received: 13 September 2017 - Discussion started: 12 October 2017

Revised: 10 February 2018 - Accepted: 13 March 2018 - Published: 12 April 2018

\begin{abstract}
In this paper we assessed the influence of biomass burning during forest fires throughout summer (1 June31 August) 2010 on aerosol abundance, dynamics, and its properties over Ukraine. We also considered influences and effects over neighboring countries: European Russia, Estonia, Belarus, Poland, Moldova, and Romania.

We used MODIS satellite instrument data to study fire distribution. We also used ground-based remote measurements from the international sun photometer network AERONET plus MODIS and CALIOP satellite instrument data to determine the aerosol content and optical properties in the atmosphere over Eastern Europe. We applied the HYSPLIT model to investigate atmospheric dynamics and model pathways of particle transport.

As with previous studies, we found that the highest aerosol content was observed over Moscow in the first half of $\mathrm{Au}-$ gust 2010 due to the proximity of the most active fires. Large temporal variability of the aerosol content with pronounced pollution peaks during 7-17 August was observed at the Ukrainian (Kyiv and Sevastopol), Belarusian (Minsk), Estonian (Toravere), and Romanian (Bucharest) AERONET sites.

We analyzed aerosol spatiotemporal distribution over Ukraine using MODIS AOD $550 \mathrm{~nm}$ and further compared with the Kyiv AERONET site sun photometer measurements; we also compared CALIOP AOD $532 \mathrm{~nm}$ with MODIS AOD data. We analyzed vertical distribution of aerosol extinction at $532 \mathrm{~nm}$, retrieved from CALIOP measurements, for the territory of Ukraine at locations where high AOD values were observed during intense fires. We estimated the influence of fires on the spectral single scattering albedo, size distribution, and complex refractive indices us-
\end{abstract}

ing Kyiv AERONET measurements performed during summer 2010.

In this study we showed that the maximum AOD in the atmosphere over Ukraine recorded in summer 2010 was caused by particle transport from the forest fires in Russia. Those fires caused the highest AOD $500 \mathrm{~nm}$ over the Kyiv site, which in August 2010 exceeded multiannual monthly mean for the entire observational period (2008-2016, excluding 2010) by a factor of 2.2. Also, the influence of fires resulted in a change of the particle microphysics in the polluted regions.

\section{Introduction}

Biomass burning during wildfires is an important global source of trace gases and aerosol in the atmosphere (Seiler and Crutzen, 1980; Crutzen and Andreae, 1990). Wildfires as a mixture of peat burning and forest fires contribute significantly to the fine-mode (particle size $<1 \mu \mathrm{m}$ ) aerosol optical depth (AOD; Barnaba et al., 2011). According to Barnaba et al. (2011), "the largest numbers of these fires occur in Africa, Asia and South America, but a not negligible fraction also occurs in Eastern Europe and former USSR countries, particularly in the Russian Federation, Ukraine and Kazakhstan".

Extensive wildfires during summer (1 June-31 August) 2010 over the European territory of Russia (ETR) and parts of Eastern Europe were caused by an extreme heat wave that led to an all-time maximum temperature record over numerous locations (Barriopedro et al., 2011; 
Dole et al., 2011; Demirtaş, 2017), including the territory of Ukraine (Shevchenko et al., 2014). High surface temperatures $\left(35-41^{\circ} \mathrm{C}\right)$ and low relative humidity $(9-28 \%)$ over those regions (Witte et al., 2011) favored the occurrence and persistence of fires. In turn, those fires caused significant air pollution in populated areas of Russia and combustion products (gases and aerosol) were spread over large areas of Eastern Europe.

For several years great effort has been devoted to the study of the spatiotemporal distribution of aerosol in summer 2010 over the ETR and Eastern Europe. For example, Konovalov et al. (2011) analyzed the evolution of nearsurface concentrations of carbon monoxide, $\mathrm{PM}_{10}$, and ozone in the Moscow region by comparing ground-based and satellite measurements with the modified version of the multiscale chemistry-transport model for atmospheric composition analysis and forecast CHIMERE (http://www.lmd. polytechnique.fr/chimere/). They used fire radiative power data retrieved from the Moderate Resolution Imaging Spectrometer (MODIS) on board National Aeronautics and Space Administration (NASA) Aqua and Terra satellites to study the spatiotemporal variability of the fires. They also used MODIS AOD $550 \mathrm{~nm}$ to correct a negative bias in fire radiative power measurements in case the fires obscured by heavy smoke. They found that "extreme air pollution episodes in Moscow were mainly caused by fires taking place at relatively short range (less than $200 \mathrm{~km}$ ) from Moscow; the transport of air pollution to Moscow from more distant fires was less significant. It was also found that a compensation of a possible negative bias in the measured radiative power from fire obscured by heavy smoke is a crucial condition for a good performance of the model".

Active fires during summer 2010 influenced the content and properties of aerosol in the atmosphere both above burning areas and over the most territory of Eastern Europe, where the fires were not as strong as in the ETR and eastern Ukraine. The tropospheric dynamics of aerosol pollution over those territories was studied by Witte et al. (2011) using ground-based and satellite observations. They applied data from satellite instruments MODIS and Ozone Monitoring Instrument (OMI) in the area between $45-63^{\circ} \mathrm{N}$ and $23-63^{\circ} \mathrm{E}$ (covering the territory of Ukraine). They studied the spatiotemporal distribution and energy characteristics of burning cells using MODIS fire products and AOD at $550 \mathrm{~nm}$, OMI aerosol index (AI) at $354 \mathrm{~nm}$, and AOD and single scattering albedo (SSA), both at $388 \mathrm{~nm}$. Their results correlated well with the development of weather conditions determined by back trajectory simulations with the starting point in Moscow. They determined vertical temperature profiles, pressure, humidity, and wind directions according to radiosonde measurements over the ETR. Witte et al. (2011) showed that the aerosol pollution of the atmosphere over the Ukrainian territory was significantly lower in comparison with western and central regions of the ETR.
Chubarova et al. (2012) analyzed aerosol properties and radiative effects during the 2010 fire events in central Russia according to ground-based measurements of AErosol RObotic NETwork (AERONET) in Moscow and Zvenigorod, as well as radiative measurements with World Meteorological Organization (WMO) calibrated pyranometers located in Moscow. They showed that an extremely high AOD was observed in Moscow and its suburbs on 6-8 August, with an absolute maximum at $500 \mathrm{~nm}$ on 7 August, reaching 6.4 at Moscow and 5.9 at Zvenigorod. They retrieved spatial distribution of AOD for those dates using MODIS satellite data. Chubarova et al. (2012) analyzed the way smoke affected aerosol particle size distribution, refractive index (RI), SSA, and the phase function asymmetry factor. Those quantities, measured during fire events, were compared (1) with those obtained earlier between fire events in the same regions and (2) with analogous aerosol properties determined during wildfires but at other areas of the globe. They also explored the impact of intense fires on the environment. A significant change in the atmospheric gas composition, aerosol concentration, and air temperature caused detrimental influence on human health. Particularly the mortality rate increased by 1.5-1.6 times in the central region of the ETR during summer 2010 (Chubarova et al., 2012).

Péré et al. (2014) described the aerosol shortwave direct radiative forcing during the peak of the 2010 Russian wildfires and their impact on air temperature and atmospheric dynamics. They applied the CHIMERE offline coupled to the mesoscale Weather Research and Forecasting community model. The authors analyzed the impact of fine aerosol $(10 \mathrm{~nm}-5 \mu \mathrm{m})$ on shortwave $(0.2-6 \mu \mathrm{m})$ solar radiation. They simulated aerosol direct radiative forcing and feedbacks in the atmosphere for the period 5-12 August 2010 from observational data obtained with ground-based AERONET sun photometers as well as POLarization and Directionality of the Earth's Reflectances (POLDER) and Cloud-Aerosol Lidar with Orthogonal Polarization (CALIOP) satellite instruments. They analyzed AOD, SSA, and asymmetry factor of aerosol. They also determined the vertical distribution of aerosol from the vertical profiles of CALIOP extinction coefficient measurements at $532 \mathrm{~nm}$ wavelength. The authors detected strong perturbations of atmospheric composition over Russia from those data. Moscow was subjected to an important aerosol radiative effect, especially during the arrival of the aerosol plume on 6-10 August.

Despite previous studies focused on the summer 2010 fires in the ETR and Eastern Europe, little attention was paid to aerosol impact over Ukraine, which, as we show in this study, was also influenced by severe fires. Therefore, thorough studies on aerosol layer properties over Ukraine require further attention. To the authors' best knowledge, very few publications can be found regarding this topic. For example, Danylevsky et al. $(2011 \mathrm{a}, \mathrm{b})$ analyzed aerosol layer properties from AERONET/PHOtométrie pour le Traitement Opérationnel de Normalisation Satelli- 
taire (PHOTONS) ground-based measurements over one of Ukraine's largest cities, Kyiv, during 2008-2009. Bovchaliuk et al. (2013) and Milinevsky et al. (2014) analyzed aerosol variability, its seasonal dynamics, and the load of anthropogenic aerosol over the industrial areas over Ukraine using POLDER satellite and AERONET ground-based measurements. Bovchaliuk et al. (2013) showed that the maximum measured AOD at $870 \mathrm{~nm}$ over the analyzed region (40-60 ${ }^{\circ} \mathrm{N}$ and $20-50^{\circ} \mathrm{E}$ ) during 2003-2011 was observed in summer 2010 due to the transport of aerosol from Russian wildfires. Milinevsky et al. (2014) analyzed seasonal variations of the aerosol load for the period 2008-2013 over eight Ukrainian cities (including Kyiv) and Belarus (only Minsk). They also found a smoke-particle-induced increase of AOD $440 \mathrm{~nm}$ over the Kyiv site that could be traced back to biomass burning in the ETR in August 2010.

Our research contributes significantly to the abovementioned studies of Bovchaliuk et al. (2013) and Milinevsky et al. (2014), but, unlike them, we focused on a comprehensive evaluation of the impact of the fires in summer 2010 on the tropospheric aerosol load with a major focus on Ukraine. We used data from ground-based AERONET sun photometer measurements and satellite measurements from MODIS (Aqua and Terra) and CALIOP instruments. We reproduced the weather conditions with the HYbrid Single-Particle Lagrangian Integrated Trajectory (HYSPLIT) model. We computed trajectories of aerosol polluted air to the 10 AERONET sites in the ETR, Eastern Europe, and Ukraine in the lowest $5 \mathrm{~km}$ tropospheric layer. We also estimated the spatiotemporal influence of extensive wildfires in the ETR and Eastern Europe on air pollution caused by aerosol over Ukraine and neighboring areas. Combined measurements of those events of AERONET sun photometer in Ukraine and the two satellite instruments MODIS and CALIOP have not been analyzed before. Also, in contrast to earlier studies, we provided deeper insight into aerosol properties other than AOD and the vertical structure of the relevant tropospheric aerosol layers.

\section{Methods and data sources}

\subsection{AERONET data}

The automatic sun photometer network AERONET was founded by NASA and PHOTONS (Lille University of Science and Technology, National Centre for Space Studies (CNES), and the National Center for Scientific Research of France (CNRS)) and includes several hundreds of sites over the world. The basic principle of the network is to standardize the equipment, measurement techniques, and data processing, which are stored in a freely accessible centralized database. The description of instruments and measurements procedures, calibration of sun photometers, accuracy of measurements, and terminology are described in Holben et al. (1998) and in the documentation from the AERONET web page (http://aeronet.gsfc.nasa.gov/). According to the AERONET classification, all observed data are divided into three levels: Level 1.0 is primary unscreened data; Level 1.5 is cloud-screened data; and Level 2.0 is the highest accuracy data, cloud-screened, quality-controlled, and corrected for sun photometers recalibration. We used Level 2.0 data in our research. The spectral AOD in the atmospheric column over the observational site is determined from direct solar irradiance measurements with errors of \pm 0.01 in the visible and near-infrared regions of the spectrum and with a larger uncertainty $( \pm 0.02)$ in the ultraviolet band (Holben et al., 1998). The Ångström exponent (AE) is also determined by the AERONET algorithm for the sun photometer spectral range $340-870 \mathrm{~nm}$ from direct sun irradiance measurements. We used AE to interpolate the AOD on the required wavelength. We applied AE determined for 440-870 $\mathrm{nm}$ because it is suitable to the aerosol size distribution during wildfires when relative dominance of the fine-mode particles takes place (Eck et al., 1999; Holben et al., 2001).

To assess the extent of the impact of wildfires in summer 2010 we used data from the following Eastern European AERONET sites (also shown in Fig. 1): Minsk (Belarus), Moscow (Russian Federation), Toravere (Estonia), Belsk (Poland), Moldova (the official name of the site is Moldova, although it is located in Chisinau, Moldova), ClujNapoca, Bucharest, and Eforie (all Romania). We also used data from the only two Ukrainian sites that measured during summer 2010: Kyiv and Sevastopol.

To analyze aerosol dynamics over Ukraine during the Russian wildfires in summer 2010, we used AERONET data mostly from the Kyiv site. Measurements of aerosol properties over Kyiv by AERONET sun photometers started at the end of March 2008 (Danylevsky et al., 2011a). The Kyiv PHOTONS/AERONET site is located at the Main Astronomical Observatory of the National Academy of Sciences of Ukraine in the Golosiiv forest located in the southern part of Kyiv, approximately $10 \mathrm{~km}$ from the city center. The surrounding landscape around the Kyiv site enables the sun photometer to scan the entire celestial hemisphere. Data are sent to AERONET database twice a day and are accessed and displayed on the Kyiv AERONET website on the same day. Up to 2013 the site was equipped with CIMEL CE-318-2 sun photometer polarized model with filters of 440, 670, 870, 936, and $1020 \mathrm{~nm}$. We obtained AOD $500 \mathrm{~nm}$ data for the Kyiv site by data interpolation using Ångström formula in the range of $440-870 \mathrm{~nm}$. Similarly, we obtained AOD $550 \mathrm{~nm}$ for the Kyiv site by data interpolation using Angström formula in the range of $440-675 \mathrm{~nm}$. We calculated AOD values at different wavelengths to be further consistent with measurements, performed by different types of sun photometer and MODIS satellite instrument. 


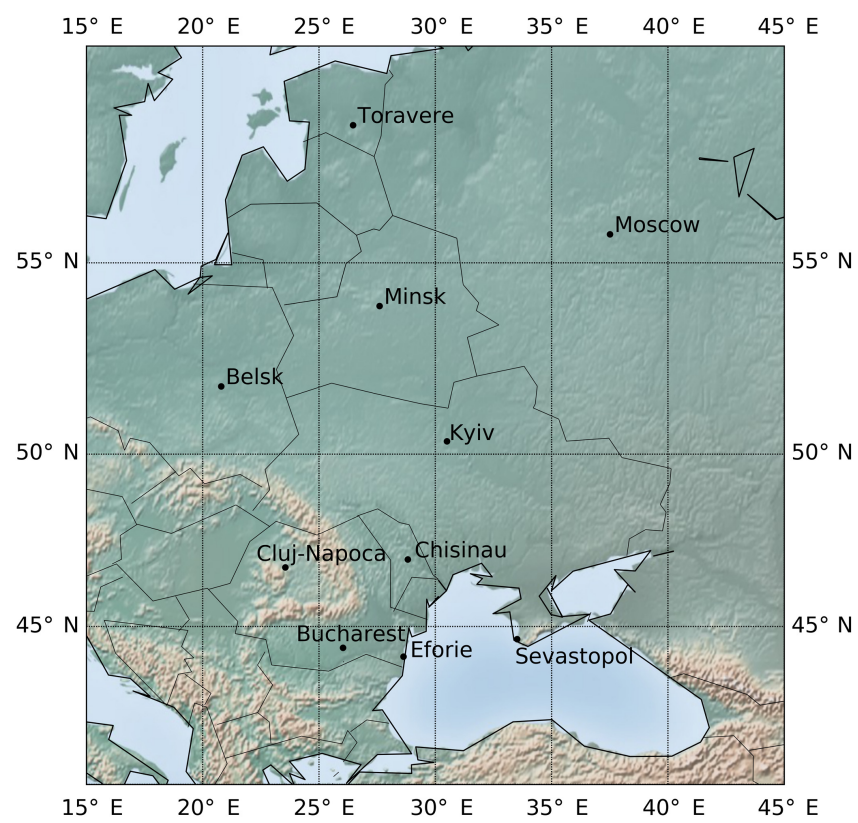

Figure 1. AERONET observational sites in Eastern Europe and Ukraine used in this study.

\subsection{MODIS data}

Two MODIS instruments are installed on board the Terra (EOS AM-1) and Aqua (EOS PM-1) satellites. Terra (http:// terra.nasa.gov/about/) flies in a sun-synchronous, near-polar, circular orbit with an inclination of $98.5^{\circ}$ at an altitude of $705 \mathrm{~km}$ every $98 \mathrm{~min}$ (16 orbits per day). The local equatorial crossing time is approximately 10:30 in a descending node. The Aqua satellite belongs to the A-Train constellation (http://atrain.gsfc.nasa.gov). The local equatorial crossing time is approximately 13:30 in an ascending node of a sun-synchronous, near-polar, circular orbit. The MODIS instruments supply data used to study the Earth's surface and atmosphere from local to global scales. Over land, aerosol properties are retrieved from spectral channels $0.47,0.66$, and $2.12 \mu \mathrm{m}$. One of the primary aerosol products of the MODIS algorithms is the AOD at $550 \mathrm{~nm}$ in the atmosphere over land and ocean (Remer et al., 2005, 2008; Levy et al., 2007, 2010, 2013).

To estimate atmospheric pollution over Ukraine caused by aerosol from wildfires, we used AOD $550 \mathrm{~nm}$ retrieved by the land algorithm and collected in the MODIS Aqua and Terra Level 2 Collection 005 and 051 Optical_Depth_Land_And_Ocean product file (see https://modis-images.gsfc.nasa. gov/_docs/ATBD_MOD04_C005_rev2.pdf, https: //modis-images.gsfc.nasa.gov/MOD04_L2/format.html).

The documentation of the MODIS Level 2 Collection 051 Optical_Depth_Land_And_Ocean dataset (Levy et al., 2009) does not recommend the application of these data for quantitative analysis. Nevertheless we applied these data because the alternatively recommended dataset Corrected_Optical_Depth_Land contains only a very small amount of data in the regions for the period we considered in this study. Earlier studies based on the Optical_Depth_Land_And_Ocean product showed good agreement between AOD MODIS (quality assurance confidence (QAC) flags 1, 2, and 3) and AERONET on a global scale (Remer et al., 2008; Levy et al., 2010; Bréon et al., 2011). Local biases for special cases of aerosol pollution, such as wildfires, were reported by Levy et al. (2010). At this stage we applied all data over the land with QAC flags 1, 2 , and 3 from the dataset without any additional filtering. For comparably clean atmospheric conditions, when AOD is close to zero, AOD values within \pm 0.05 are practically indistinguishable (Remer et al., 2005, 2008; Levy et al., 2009). Following Levy et al. (2009), we set corresponding data within this range to zero.

We compared MODIS Collection 5 data with AERONET data from the Kyiv site to further examine potential regional peculiarities in the satellite measurements. To define spatial collocations we computed distances and azimuth angles between the centers of each MODIS image pixel and the location of the Kyiv AERONET site. To compare AOD from MODIS and AERONET we averaged the MODIS AOD over the pixels area centered on the Kyiv AERONET site. We did not calculate the spatial biases of the AOD over this area. This simplification of the Ichoku et al. (2002) procedure is acceptable because MODIS images of land do not exceed an area of $50 \times 50 \mathrm{~km}$, which is significantly less than the characteristic dimension of inhomogeneities in the spatial distribution of aerosol in the atmosphere (Anderson et al., 2003). In addition, if several AERONET AOD measurements were available, we chose only one, performed at the closest time to the satellite measurement (not more than $30 \mathrm{~min}$ ).

The MODIS mission also provides fire mapping on a land surface, which we used to evaluate the activity of fires and their spatial distribution, similarly to Witte et al. (2011). For detecting fires and defining their characteristics, the MODIS data processing algorithm uses two spectral channels (4 and $11 \mu \mathrm{m}$; Justice et al., 2002). Combustion temperature (in K) is defined from the measurements of the spectral brightness of the flame, applying the Stefan-Boltzmann law. An algorithm is applied to calculate the number of burning cells and the total area occupied by fires. Data of the spatiotemporal distribution of fires are freely available online from NASA (e.g., https://firms.modaps.eosdis.nasa.gov/map/). To visualize the spatial distribution of fires we used data supplied by the University of Maryland (ftp://fuoco.geog.umd.edu). We applied high-confidence (confidence level of calculated fire pixels is larger than $80 \%$ ) brightness temperature of fire pixels (at band 21). More information about the algorithms of fire recognition, principles of archiving, and distributing data can be found in Schroeder et al. (2008), Davies et al. (2009), and Justice et al. (2011). MODIS sometimes detects volcanic 
eruptions or flares of gas in addition to vegetation fires. Here, we considered all observed signals as wildfires.

\subsection{CALIOP data}

CALIOP is a two-wavelength (532 and $1064 \mathrm{~nm}$ ) polarization lidar providing high-resolution vertical profiles of aerosol and clouds. It is installed on board the NASA CloudAerosol Lidar and Infrared Pathfinder Satellite Observations (CALIPSO) satellite, which belongs to the A-Train constellation. A detailed description is provided on its official website (http://www-calipso.larc.nasa.gov/about/) as well as in Winker et al. (2003) and Hunt et al. (2009). CALIOP uses three receiver channels: one measures the $1064 \mathrm{~nm}$ backscatter intensity and two channels measure orthogonally polarized components of the $532 \mathrm{~nm}$ backscattered signal. The laser beam is directed almost at nadir with a slight forward tilt in the direction of motion of the satellite to avoid direct reflection of laser radiation from high-reflectivity objects (surface water, snow, etc.). The divergence of the transmitted laser beam equals $100 \mu \mathrm{rad}$. This results in a footprint on the Earth's surface, called in our paper ground track, of about $70 \mathrm{~m}$. A pulse repetition rate of approximately $20 \mathrm{~Hz}$ provides vertical resolution of $15 \mathrm{~m}$.

CALIOP measurements allow to derive the vertical distribution of aerosol and clouds. The corresponding AOD is determined by extinction coefficient integration over altitude (Omar et al., 2009; Vaughan et al., 2009; Winker et al., 2009; Young et al., 2013). For this study we used both parameters, vertical distribution of the extinction coefficient and AOD at $532 \mathrm{~nm}$, defined along the path of the sub-satellite point. We applied Level 2 Cloud and Aerosol Layer and Profile products V 3.01 and 3.02 with a resolution of $5 \mathrm{~km}$ on the surface along the sub-satellite point.

A comparison of CALIOP AOD with ground-based AERONET observations can be challenging because of different measurement characteristics of both instruments. The CALIOP lidar provides only fragmentary data on aerosol along CALIPSO satellite's ground track due to the small size of its light beam and cloudy conditions that frequently occur. As long as the instrument's orbital period lasts $98 \mathrm{~min}$, ground tracks of satellite consecutive passages at certain latitudes are shifted $24.5^{\circ}$ to the west, making its spatiotemporal coverage rather sparse. Consequently, the probability of CALIOP to pass over the atmospheric column observed by the solar photometer AERONET is rather limited (e.g., Redemann et al., 2012). During the three summer months of 2010 we found no coincident CALIOP and AERONET measurements over Kyiv, apart from the single collocation, although not exactly matching the selection criteria according to Omar et al. (2013). In this particular case the closest CALIPSO ground track was found $60 \mathrm{~km}$ eastwards from the Kyiv AERONET site.

Therefore, in this study we only compared CALIPSO/CALIOP Cloud Aerosol Layer Product AOD
532 nm (Winker et al., 2009; Winker et al., 2010) with Aqua MODIS AOD $550 \mathrm{~nm}$ since the orbits of both satellites are in the A-Train constellation (http://atrain.nasa.gov/). The relative positions of CALIPSO and Aqua satellites in the A-Train provide a large number of practically simultaneous measurements with the time span of $2 \mathrm{~min}$, while the spatial difference is only about $10 \mathrm{~km}$. Each granule of MODIS data consists of consecutive scans across the satellite track. The footprint of CALIOP light beam on this granule looks like a sequence of points on the straight line, which are passing close to the center of a granule. Each of these points represent the center of the CALIOP measurement averaged over $5 \mathrm{~km}$, which matches with one of the pixels of a MODIS granule. To find these matches we calculated the distances and azimuth angles between the center of each CALIOP point and the center of each pixel in MODIS granule in the same manner as for the MODIS-AERONET case, described in Sect. 2.2. We averaged MODIS data over areas $50 \mathrm{~km} \times 50 \mathrm{~km}$, while CALIOP data in the CALIPSO Cloud Aerosol Layer Product are averaged on various distances along the satellite ground track, up to $80 \mathrm{~km}$ (see CALIPSO Quality Statements: Lidar Level 2 Cloud and Aerosol Layer Products, Version Releases: 3.01, 3.02). We did not apply any correction for potential spectral differences while comparing CALIOP AOD $532 \mathrm{~nm}$ and Aqua MODIS AOD $550 \mathrm{~nm}$. It yields to an estimated systematic bias in our AOD comparison of approximately $2-6 \%$ in the AE range between 0.5 and 1.8 (see Fig. 5b) and can be neglected in our cases, following Kittaka et al. (2011).

\subsection{Weather conditions and transport of air masses}

To analyze the impact of weather conditions on the distribution of aerosol in the atmosphere during summer 2010, we used weather charts from the Ukrainian Weather Service of isobaric surfaces representing altitudes of $2 \mathrm{~m}, 1.5$, 3 , and $5 \mathrm{~km}$ (not shown in this paper). We also considered weather charts at $500 / 1015 \mathrm{hPa}$ of the Global Forecast System (GFS; http://www.wetterzentrale.de) from the National Centers for Environmental Prediction (NCEP) and merged global and European model (GME; http://www.wetter3.de) from the German Weather Service.

To confirm the analysis of weather charts, we also calculated trajectories of air masses using the HYSPLIT model (http://ready.arl.noaa.gov/HYSPLIT.php), developed by the National Oceanic and Atmospheric Administration's (NOAA) Air Resources Laboratory (Draxler and Hess, 1998; Bowman et al., 2013). Furthermore, to study the aerosol inflow towards AERONET sites shown in Fig. 1, we computed back trajectories of air masses at different heights for dates of maximum measured AOD at each of those sites. Back trajectories were simulated for $168 \mathrm{~h}$ (7 days) at altitudes of $500 \mathrm{~m}$, $1.5,3,4$, and $5 \mathrm{~km}$ at 12:00 GMT starting time. We chose the lowermost $5 \mathrm{~km}$ tropospheric altitudes, taking into account the analysis of the vertical distribution of aerosol according 

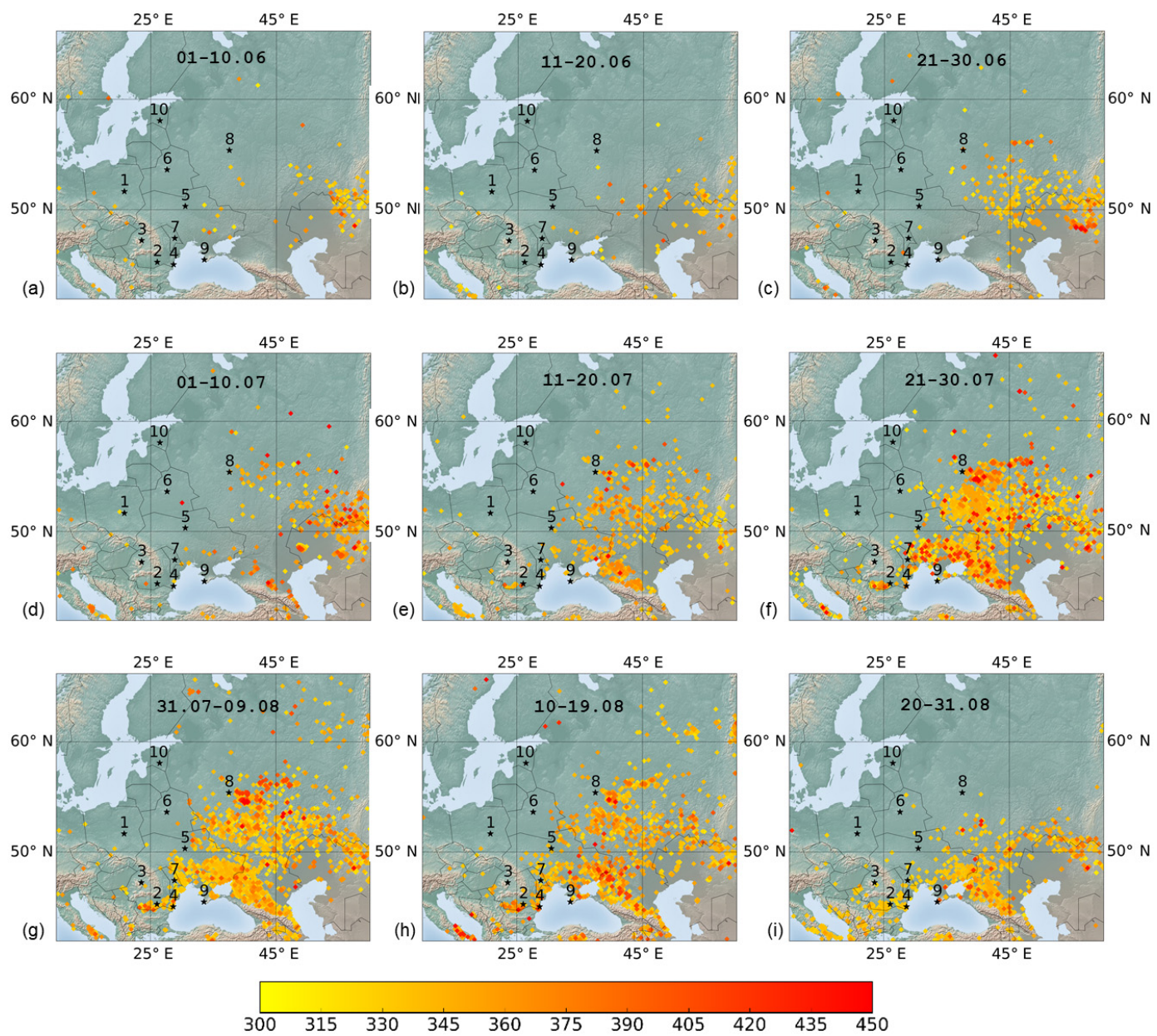

Figure 2. Fire locations and brightness temperature (in K) of fire pixels in the ETR and Eastern Europe $\left(40-65^{\circ} \mathrm{N}\right.$ and $\left.10-60^{\circ} \mathrm{E}\right)$ detected by MODIS and accumulated over 10-day periods from 1 June to 20 August - (a) 1-10 June, (b) 11-20 June, (c) 21-30 June, (d) 1-10 July, (e) 11-20 July, (f) 21-30 July, (g) 31 July-9 August, (h) 10-19 August - and a 12-day period of (i) 20-31 August. Black stars and numbers indicate the position of AERONET stations also shown in Fig. 1: 1 - Belsk; 2 - Bucharest; 3 - Cluj-Napoca; 4 - Eforie; 5 - Kyiv; 6 - Minsk; 7 - Moldova; 8 - Moscow; 9 - Sevastopol; 10 - Toravere.

to CALIOP data (shown in Sect. 3.3.2). According to Stohl (2002), the uncertainty of calculated HYSPLIT trajectories for a period longer than $24 \mathrm{~h}$ is around $20 \%$ in the horizontal direction in the free troposphere; after $120 \mathrm{~h}$ the uncertainty increases to about $400 \mathrm{~km}$ in the horizontal and about $1300 \mathrm{~m}$ in the vertical planes.

\section{Results and discussion}

\subsection{Impact of wildfires and weather conditions during summer 2010 on aerosol air pollution in Eastern Europe}

To analyze the impact of wildfires on aerosol loading, we plotted distributions and brightness temperature of the fire pixels over the ETR and Eastern Europe (40-65 $\mathrm{N}$ and 10 $60^{\circ} \mathrm{E}$ ) in summer 2010 as observed by MODIS (Fig. 2). Each map accumulates fire pixels over 10-day periods from 1 June to 31 August, except Fig. 2i, which covers a 12-day period during 20-31 August. Black stars and numbers in Fig. 2 indicate the position of the AERONET stations. Figure 3 shows time series of the total number of fire pixels per day in the same area as in Fig. 2. Figure 3 indicates that the fire activities increased from mid-July throughout Eastern Europe. The largest number of fires was observed in the ETR, Ukraine, and Moldova. Both the overall number and the brightness temperature of fires reached their maximum between 26 July and 18 August. The largest number of fires, as well as the largest brightness temperature, were observed on 29 July (Figs. 2f and 3). Such large fire areas, high brightness temperature, and long duration were caused by specific weather conditions over the ETR and Eastern Europe during the second half of summer 2010. This favored the accumulation of 
Table 1. Level of air pollution caused by aerosol (AOD $500 \mathrm{~nm}$ ) from 1 June to 31 August 2010 over the ETR and Eastern Europe according to AERONET.

\begin{tabular}{llrrrrrr}
\hline No. & Site & $\begin{array}{r}\text { Number of } \\
\text { meas. }\end{array}$ & $\begin{array}{r}\text { Mean } \\
\text { AOD }\end{array}$ & $\begin{array}{r}\text { SD } \\
\text { AOD }\end{array}$ & $\begin{array}{r}\text { Max } \\
\text { AOD }\end{array}$ & $\begin{array}{r}\text { Date of } \\
\text { max AOD }\end{array}$ \\
\hline 1 & Belsk & 1938 & 0.18 & 0.11 & 0.05 & 0.74 & $16-07-10$ \\
2 & Bucharest & 2381 & 0.30 & 0.16 & 0.06 & 0.97 & $17-08-10$ \\
3 & Cluj-Napoca & 1220 & 0.25 & 0.13 & 0.04 & 0.62 & $01-08-10$ \\
4 & Eforie & 1855 & 0.24 & 0.10 & 0.06 & 0.59 & $01-08-10$ \\
5 & Kyiv & 2732 & 0.30 & 0.20 & 0.05 & 1.26 & $15-08-10$ \\
6 & Minsk & 1368 & 0.25 & 0.20 & 0.04 & 1.27 & $17-08-10$ \\
7 & Moldova & 1343 & 0.22 & 0.11 & 0.05 & 0.62 & $13-07-10$ \\
8 & Moscow & 1573 & 0.36 & 0.46 & 0.05 & 4.62 & $07-08-10$ \\
9 & Sevastopol & 3564 & 0.23 & 0.12 & 0.04 & 0.93 & $16-08-10$ \\
10 & Toravere & 1296 & 0.20 & 0.19 & 0.03 & 1.23 & $07-08-10$ \\
\hline
\end{tabular}

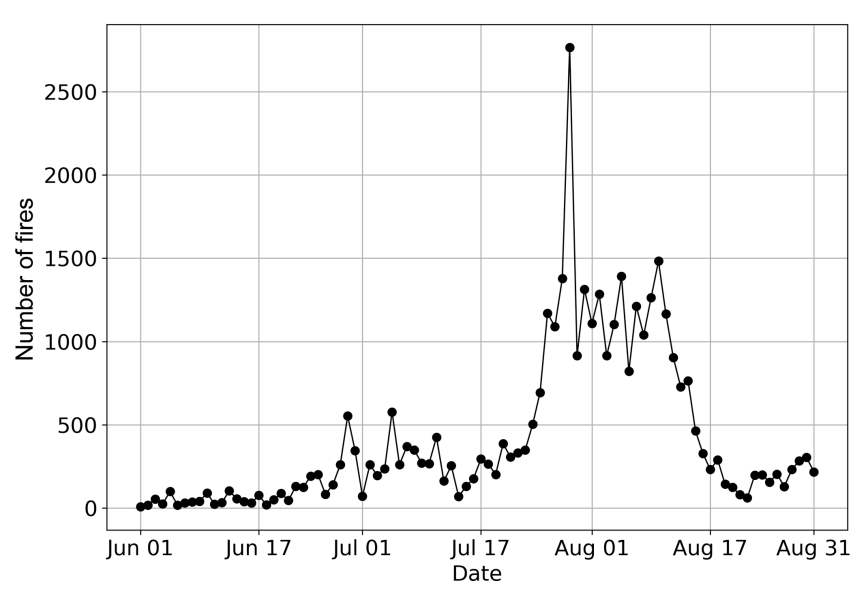

Figure 3. Total amount of fire pixels for each day of summer 2010 according to MODIS Aqua and Terra data over the area shown in Fig. $1\left(40-65^{\circ} \mathrm{N}\right.$ and $\left.10-60^{\circ} \mathrm{E}\right)$.

aerosol in the atmosphere over these regions (Witte et al., 2011; Chubarova et al., 2012; Péré et al., 2014).

Ground-based AERONET observations showed an increased aerosol content over the Eastern European sites during July and August 2010. We analyzed changes in AOD at $500 \mathrm{~nm}$ using all daily averaged measurements from 1 June to 31 August from the AERONET database for Minsk (Belarus), Moscow (Russian Federation), Toravere (Estonia), Belsk (Poland), Moldova (Chisinau/Moldova), Cluj-Napoca, Bucharest, Eforie (all Romania), and Kyiv and Sevastopol (both Ukraine). The analysis revealed significant temporal dynamics of the aerosol content with pronounced peaks during 15-17 August in Kyiv, Sevastopol, Minsk, and Bucharest (see Table 1). Also, the highest AOD values were observed in Romania (Cluj-Napoca and Eforie sites) on August 1, in Moscow and Toravere on 7 August, and in Moldova and Belsk in July (observations in Moldova from 25 July until October were not available). The highest air pollution among all analyzed sites caused by aerosol was detected in Moscow in the first half of August due to the proximity of the most active fires (e.g., Konovalov et al., 2011; Witte et al., 2011; Chubarova et al., 2012).

To analyze the aerosol inflow towards AERONET sites, we calculated HYSPLIT back trajectories for dates of maximum AOD from Table 1 (Fig. 4). Our analysis of back trajectories revealed that air movements in the lower $5 \mathrm{~km}$ layer of the troposphere corresponded to anticyclonic circulation, which is seen in Fig. $4 a-j$ at various altitudes as clockwise-shaped curves. The maximum AOD values from ten AERONET sites in the ETR and Eastern Europe were formed under conditions of air stagnation and accumulation of contaminants (Witte et al., 2011).

Back trajectories for Moldova and Belsk, where the maximum AOD was observed the earliest in summer 2010 (13 and 16 July, respectively), are shown in Fig. 4a and b. The trajectories indicate that aerosol was transported to Moldova at altitudes from 0.5 to $1.5 \mathrm{~km}$ from the fires in the ETR and southeast of Ukraine (see also Fig. 2d, e). Into the region of Belsk, aerosol was transported across continental Europe $(1.5-5 \mathrm{~km})$ mostly from the Atlantic Ocean, but also from the Baltic across regions of active fires (Fig. 2) in the lower atmosphere (500 m).

Transport of aerosol to two Romanian sites (Cluj-Napoca and Eforie) with maximum AOD observed on 1 August (Fig. 4c, d) also occurred in the lowermost $1.5 \mathrm{~km}$ layer, originating from the southeast of Ukraine and Moldova (also the area with active fires). Back trajectories for Moscow and Toravere with a maximum AOD on 7 August are shown in Fig. 4e and f, respectively. Aerosol to Moscow was transported mostly from the surrounding regions with the most active fires. Air masses over Toravere (Fig. 4f) originated from Asian regions and crossed areas of active fires in southeastern Ukraine in all analyzed altitudes (Fig. 2g).

To Kyiv, where the AOD maximum was observed on 15 August, aerosol was transported in the lower $4 \mathrm{~km}$ layer from the most active fires in the ETR, Ukraine, and Moldova (Figs. 4g, 2h). On 16 August, the maximum was recorded in 


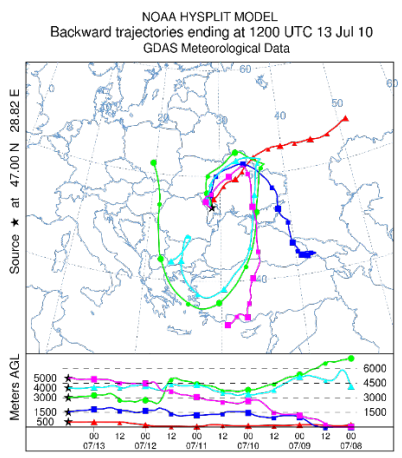

(a) Moldova

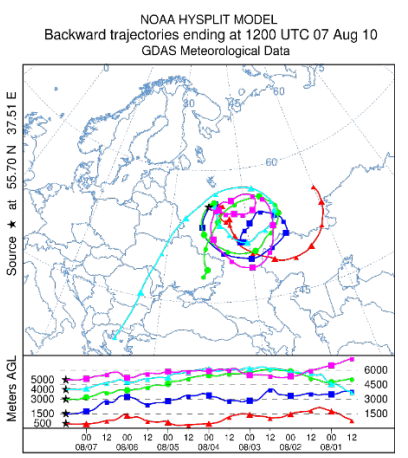

(e) Moscow

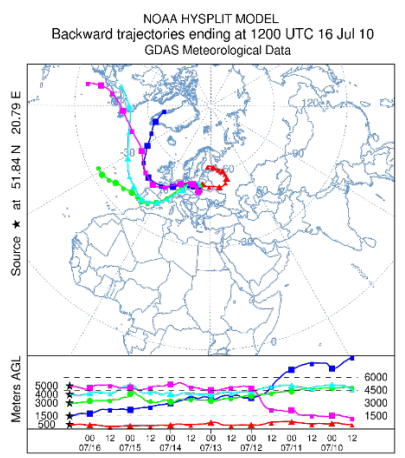

(b) Belsk

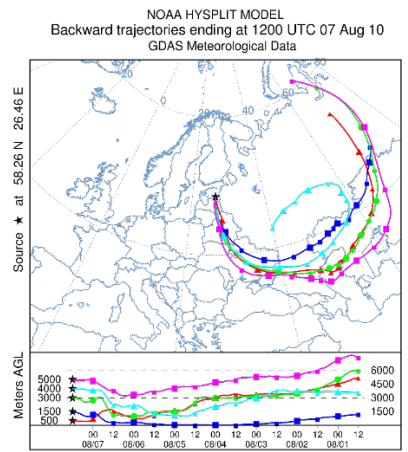

(f) Toravere

NOAA HYSPLIT MODEL

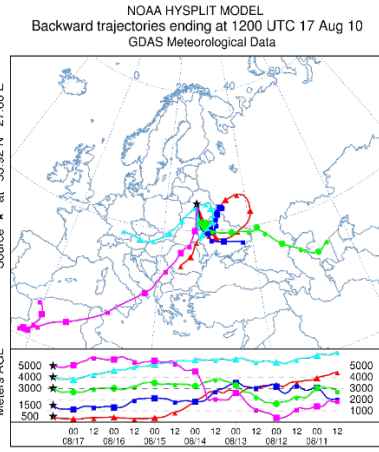

(i) Minsk

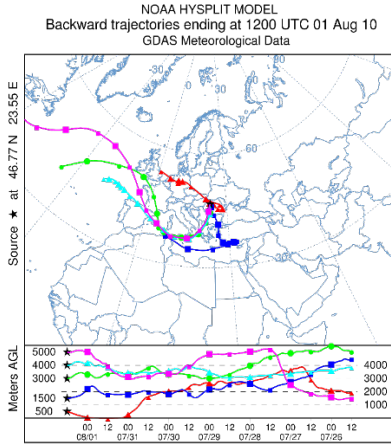

(c) Cluj-Napoca

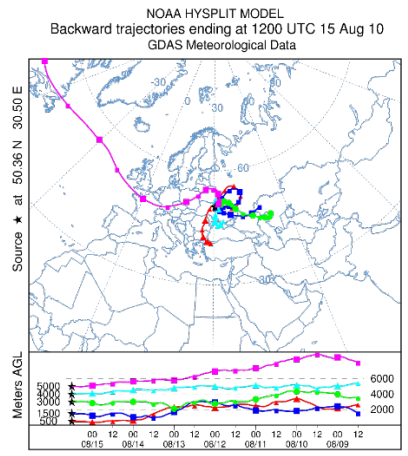

(g) Kyiv

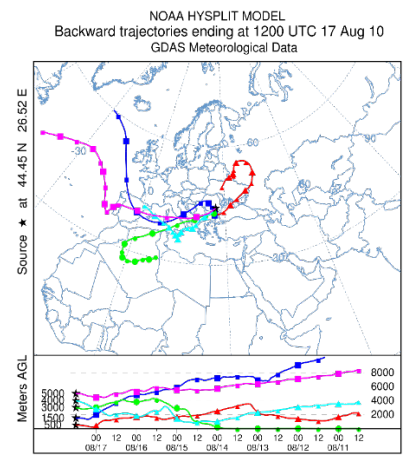

(j) Bucharest
NOAA HYSPLIT MODE

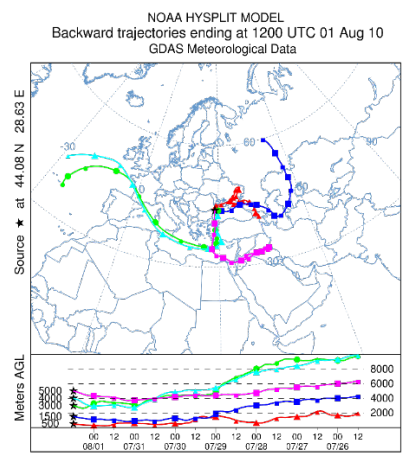

(d) Eforie

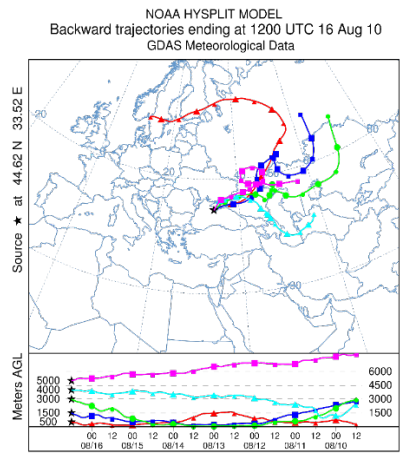

(h) Sevastopol

Figure 4. Back trajectories of air masses to the AERONET sites for dates of maximum AOD during summer 2010 (refer to Table 1).

Sevastopol on the Black Sea coast, where air masses traveled in almost the entire range of analyzed heights $(500 \mathrm{~m}-5 \mathrm{~km})$ from the ETR and Kazakhstan through the territory of active fires in the southwest of Russia (Fig. 4h). In Minsk and Bucharest the maximum AOD was observed 1 day later on 17 August (Table 1, Fig. 4i, j). Towards Minsk aerosol was transported at $3 \mathrm{~km}$ from Kazakhstan across the Caspian Sea, southern Russia, and Ukraine, where the active fires were observed; at $1.5 \mathrm{~km}$ from Ukraine; and at $500 \mathrm{~m}$ from the western regions of the ETR through Ukraine. Aerosol from fires was transported to Bucharest at $500 \mathrm{~m}$ from the northeast, specifically through the ETR and the southeast of Ukraine.
According to the monthly weather reports of the Ukrainian Weather Center, a change in weather was observed on 1821 August. Atmospheric fronts of an active cyclone which moved from the southern Baltic region to Samara led to a significant change of weather pattern in Eastern Europe. This change caused a distinct decrease in fire activities and a wet deposition of aerosol, lowering its content in the atmosphere above all investigated regions in the second half of August. 
Table 2. Annual changes of monthly averaged AOD $500 \mathrm{~nm}$ over Kyiv during the warm season for the available period from AERONET observations.

\begin{tabular}{rrrrrrrr}
\hline \multicolumn{7}{c}{ AOD 500 nm } \\
\hline Year & April & May & June & July & August & September & October \\
\hline 2008 & 0.15 & 0.21 & 0.20 & 0.14 & 0.27 & 0.25 & 0.18 \\
2009 & 0.31 & 0.21 & 0.20 & 0.20 & 0.19 & 0.23 & 0.16 \\
2010 & 0.27 & 0.17 & 0.20 & 0.27 & 0.44 & 0.12 & 0.12 \\
2011 & 0.32 & 0.20 & 0.20 & 0.27 & 0.21 & 0.19 & 0.19 \\
2012 & 0.23 & 0.20 & 0.17 & 0.21 & 0.20 & 0.13 & 0.13 \\
2013 & 0.22 & 0.17 & 0.20 & 0.14 & 0.18 & 0.14 & 0.17 \\
2014 & 0.18 & 0.17 & 0.13 & 0.17 & 0.24 & 0.15 & 0.13 \\
2015 & 0.17 & 0.17 & 0.14 & 0.21 & 0.17 & 0.24 & 0.10 \\
2016 & 0.21 & 0.17 & 0.24 & 0.29 & 0.12 & 0.15 & 0.15 \\
\hline Mean & 0.23 & 0.19 & 0.19 & 0.21 & 0.22 & 0.18 & 0.15 \\
& & & & & 0.20 (without 2010) & & \\
\hline
\end{tabular}
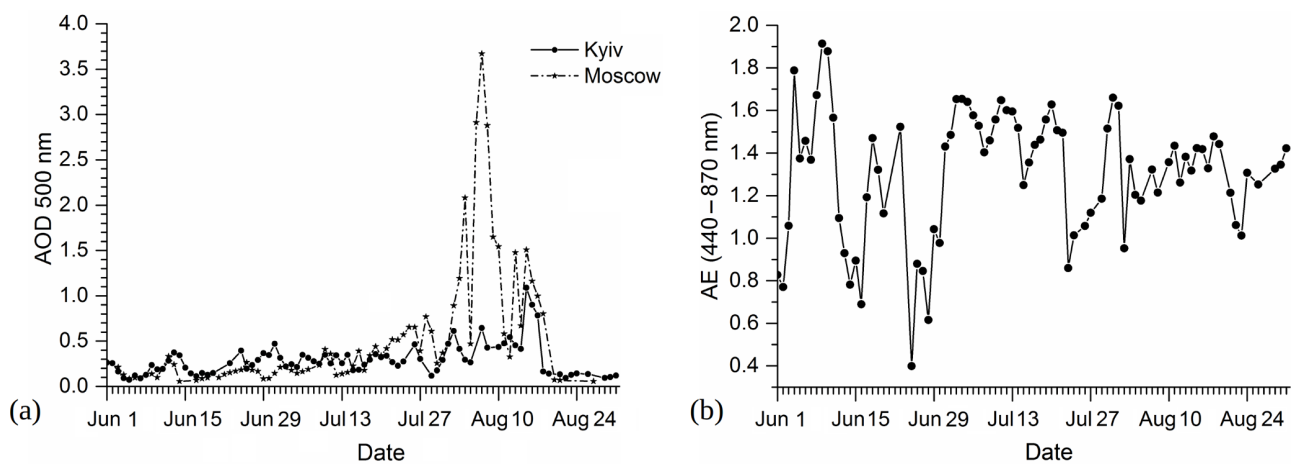

Figure 5. AOD $500 \mathrm{~nm}$ over Moscow and Kyiv (a) and AE over Kyiv (b) during 1 June-31 August 2010.

\subsection{Aerosol dynamics over Kyiv according to AERONET measurements and analysis of back trajectories}

Between 2003 and 2014 ground-based and satellite observations showed the highest aerosol content over Kyiv every year in spring (April-May) and late summer (July-August; Bovchaliuk et al., 2013; Milinevsky et al., 2014). According to both studies, the observed spring peak in aerosol content is associated with transport of the Saharan dust across Eastern Europe, transport of sea salt aerosol from the Black Sea and the Sea of Azov, and occasionally occurring agricultural fires. The summer peak results from wildfires, soil dust aerosol due to harvesting activity, and transport of Saharan dust. The lowest AOD was observed in June and the middle of autumn. In Table 2 we show a prolongation of the data record of Milinevsky et al. (2014, 2008-2013) for the Kyiv AERONET site by 3 more years up to the end of 2016. Even in this extended record the most significant aerosol pollution was observed in August 2010. This event is related, in particular, to wildfires in the ETR and Eastern Europe.
The impact of the wildfires on the AOD over Kyiv during summer 2010 was less pronounced as over Moscow (Fig. 5a). However, the aerosol pollution over Kyiv was also exceptional in comparison with the multiannual average. In August 2010, the average AOD of $500 \mathrm{~nm}$ exceeded the mean value for the same month over the entire observation period (excluding 2010) by a factor of 2.2 (see Table 2). The mean AOD at $500 \mathrm{~nm}$ for June 2010 over Kyiv was 0.20, while its daily average on 15 August 2010 was more than 5 times higher, 1.09 .

During the period from 1 June to 18 August 2010 the aerosol content over Kyiv gradually increased by more than an order of magnitude (Fig. 5a). By computing back trajectories to Kyiv at altitudes of $500 \mathrm{~m}, 1.5,3$, 4, and $5 \mathrm{~km}$, we analyzed possible sources of aerosol from various regions. We provided detailed description of AOD variations and the impact of air transport on those changes in the Fig. S1-S34 in the Supplement.

According to our analysis of air mass transport, spatiotemporal distribution of the wildfires and their brightness temperature, the wildfires were not the main source of increased AOD over Kyiv in June. Both local sources (city transport, 
heavy industry, etc.) and air transport from Western Europe determined the aerosol content and properties; hence continental and marine aerosol was dominating. In the following, we used corresponding AODs as reference values for the further estimation of the aerosol content and its properties during July and August 2010, when the wildfires took place.

From the end of June 2010 the transport of air masses to Kyiv changed significantly as shown in back trajectory simulations (Supplement Fig. S15-S16). The air masses reached Kyiv at different altitudes after crossing the regions with the wildfires. Additionally, the number and the brightness temperature of wildfires were gradually increasing during first half of July (Figs. 2 and 3). Consequently, the increase of AOD over Kyiv was caused by the accumulation of aerosol transported from the wildfire regions or was formed under the influence of combustion products. In addition, sharp increase of number of wildfires after around 20 July (Fig. 3) and their brightness temperature (Fig. $2 \mathrm{f}-\mathrm{h}$ ) contributed significantly to AOD increase over Kyiv. Observed intermediate decreases of AOD, e.g., during 29-30 July, were mostly caused by deposition from occasional rains over Kyiv. From the beginning of August until 18 August the weather conditions were stable and corresponded to anticyclonic circulation (see Sect. 3.1, Supplement Fig. S29-S32). Those conditions caused an accumulation of aerosol from wildfires over Kyiv and high AOD values, in particular on 15-17 August.

According to our analysis of $\mathrm{AE}$ values (Fig. 55b) and results received with the application of a spectral deconvolution algorithm (O'Neill et al., 2003), fine-mode aerosol predominately contributed to the observed AOD increase over Kyiv in July-August 2010. Occasionally, coarse-mode aerosol had a significant impact on the observed AOD increase and the corresponding $\mathrm{AE}$ decrease during the time when more fires burned (e.g., 23 July and 2 August; Figs. 2f$\mathrm{g}, 5 \mathrm{~b})$. This decrease could occur under the influence of local pollution in combination with weather conditions.

We also applied AERONET observations from Kyiv to analyze the impact of the wildfires on the aerosol spectral SSA and microphysical properties during summer 2010. Effective radius, size distribution (bimodal log-normal particle volume distribution), and RI (real and imaginary parts) were retrieved by Dubovik et al. (2000) and Dubovik and King (2000) by inverse solution from AERONET sun photometer measurements along the almucantar of the sun. The influence of the wildfires on the aerosol properties over Moscow and surrounding regions in summer 2010 was estimated by Witte et al. (2011), Chubarova et al. (2012), and Péré et al. (2014) by comparing them with multiannual average. In our study we estimated the impact of wildfires over Kyiv by comparing the aerosol properties for the dates when aerosol from wildfires was observed to those dates when aerosol from wildfires was absent. We identified respective dates from the analysis of air masses transport to Kyiv, as described above. We compared aerosol properties as averaged values over different time periods: (1) when the number of fires and their bright- ness temperature were low, $1-26$ June $\left(40-65^{\circ} \mathrm{N}\right.$ and 10 $60^{\circ} \mathrm{E}$, see Fig. 2); (2) when the numbers of fires significantly increased, 18 July-14 August; and (3) when the number of fires and their brightness temperature remained high and the highest AOD values were observed, 15-17 August.

We estimated the impact of fires on the aerosol size from AERONET sun photometer observations by calculating correlation coefficients between the aerosol effective radius and AOD (Fig. 6a), following the approach of Chubarova et al. (2012). The correlation coefficient for the fine mode is about 0.65 , while for the coarse mode it is only about 0.14 . This indicates that the majority of the observed AOD increase was caused by fine-mode aerosol. Changes in the aerosol size distribution in the total atmospheric column are shown in Fig. 6b. Bimodal volume distributions, inferred according to Dubovik and King (2000) and averaged over the aforementioned periods, confirm that the main contributor to the aerosol content over Kyiv was the fine mode from wildfires. This corresponds to longer atmospheric lifetime of the finemode aerosol in comparison with the coarse-mode aerosol (Seinfeld and Pandis, 2006). In the period when most fires burned (18 July-14 August), the volume distribution of both modes increased by about $30-40 \%$ due to the observed AOD increase over Kyiv. In the following 3 days (August 15-17), when maximum AOD was observed (Fig. 5a, b), only the fine mode increased further by more than a factor of 2 . Relative to the earlier period with less fire activities (1-26 June), the overall increase was about a factor of 4 . Consistently, after 18 August, when the atmosphere over Kyiv was cleaned again, the aerosol content in both modes decreased and, in turn, was even lower than during earlier periods.

The dependence of visible and near-infrared SSA from the fire activities and aerosol load over Kyiv is evident from Fig. $6 c$ by reduced values during the more intense fire period between 18 July and 14 August. Most probably, these changes were caused by an increase of the soot content in the air, which was transported from the fires. A corresponding increase of aerosol absorption in the longwave part of spectra is seen in the slope of the SSA spectral dependence, which becomes steeper. It is similar for 15-17 August, although larger SSA values were observed, which were the same level as during the period when less fires burned in June 2010. According to Eck et al. (2009), larger SSA values can be explained by the presence of the coarse-mode particle during those days (Fig. 6b), which increases the total reflectance of atmospheric column. Also increased real RI and longwave imaginary RI for the days with increased aerosol content (18 July-17 August, Fig. 6d) refer to aerosol absorption caused by wildfires. We additionally provided the daily averaged SSA as well as real and imaginary RI for 440 and $870 \mathrm{~nm}$, Level 2.0 from AERONET database, for the specific dates during summer 2010 at the Kyiv AERONET site (Table S35). 

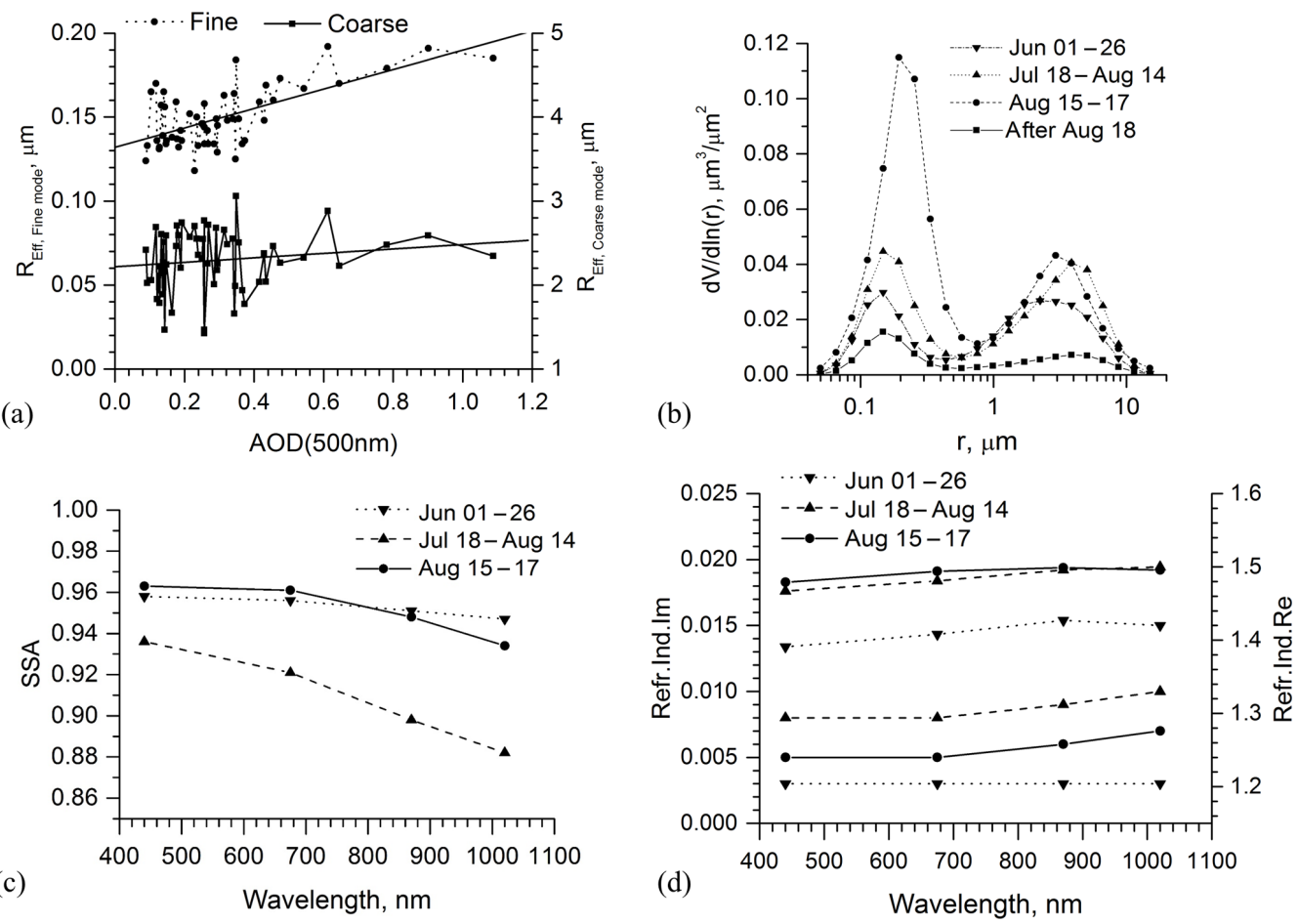

Figure 6. Aerosol spectral SSA and microphysical properties from AERONET measurements at the Kyiv site during summer 2010: (a) particle effective radius versus AOD for fine (left axis, top curves) and coarse (right axis, bottom curves) modes averaged for the entire summer 2010; (b) particle size distribution; (c) spectral SSA; (d) spectral RI, real (right axis, top curves) and imaginary (left axis, bottom curves) parts. Representative periods are 1-26 June (triangles down), 18 July-14 August (triangles up), 15-17 August (circles), and 18-31 August (squares).

\subsection{Using satellite data for estimating wildfires' influence on aerosol pollution over Ukraine}

\subsubsection{Estimations of aerosol pollution using MODIS data}

During 1 June-31 August 2010 we found 39 events for Aqua MODIS and 40 events for Terra MODIS that satisfied the collocation criteria with the AERONET Kyiv site, described in Sect. 2.2. The time span exceeded 10 min between sun photometer and Aqua MODIS measurements in eight cases and for Terra MODIS in seven cases. We approximated the comparison of MODIS AOD (AOD myd $_{\text {for }}$ Aqua MODIS and $\mathrm{AOD}_{\text {mod }}$ for Terra MODIS) with AERONET sun photometer data $\left(\mathrm{AOD}_{\mathrm{Sph}}\right)$ with a straight-line equation with the coefficients determined by the least-squares technique. We assumed that the randomly measured AOD by groundbased and satellite instruments are normally distributed. As a result, we derived the following linear equations. For Aqua MODIS, AOD myd $_{1}=-(0.09 \pm 0.02)+(1.20 \pm$ $0.06) \times \mathrm{AOD}_{\mathrm{Sph}}$ with a Pearson's correlation coefficient $R=$ 0.96 and standard deviation $\mathrm{SD}=0.07$. For Terra MODIS, $\mathrm{AOD}_{\text {mod }}=-(0.11 \pm 0.01)+(1.26 \pm 0.04) \times \mathrm{AOD}_{\mathrm{Sph}}, R=$ 0.98 , and $\mathrm{SD}=0.05$. Only $18 \%$ of AOD differences between Aqua MODIS and the sun photometer and 22.5\% between Terra MODIS and the sun photometer are out of the range $\pm\left(0.05+0.15 \times \mathrm{AOD}_{\mathrm{Sph}}\right)$, which was determined by Remer et al. (2008) and Levy et al. (2010) over land on a global scale. The correlation coefficients indicate functional relations between the AOD from AERONET and MODIS in both cases. Also, obtained regression equations showed that MODIS and AERONET AODs match well within $0.40 \leq \mathrm{AOD} \leq 0.45$.

The influence of aerosol pollution in Ukraine was interpreted from the spatial distribution of MODIS AOD $550 \mathrm{~nm}$. We analyzed data for 7 days with low AOD values, smaller than 0.5 over the Kyiv site: 6 and 7 June (Terra MODIS), 8 June (Aqua MODIS), 14 and 17 July (Aqua MODIS), 15 July (Terra MODIS), and 23 August (Terra MODIS). We also analyzed 3 days (15-17 August) with high AOD values, larger than 1.0. Figure 7 shows maps for the region 40 $60^{\circ} \mathrm{N}$ and $22.5-40^{\circ} \mathrm{E}$ of Aqua MODIS data for those 2 days when the aerosol load over the Kyiv AERONET site was low (7a, 17 July) and the highest (7b, 15 August). During the days with low aerosol content the AOD $550 \mathrm{~nm}$ was homogeneously distributed (e.g., Fig. 7a) over the whole territory. During the high pollution case, the spatial AOD distribution distinctly differed. The highest AODs were observed over northeastern and central regions of Ukraine, where AOD values reached and partly exceeded a value of 2 (Fig. 7b). 

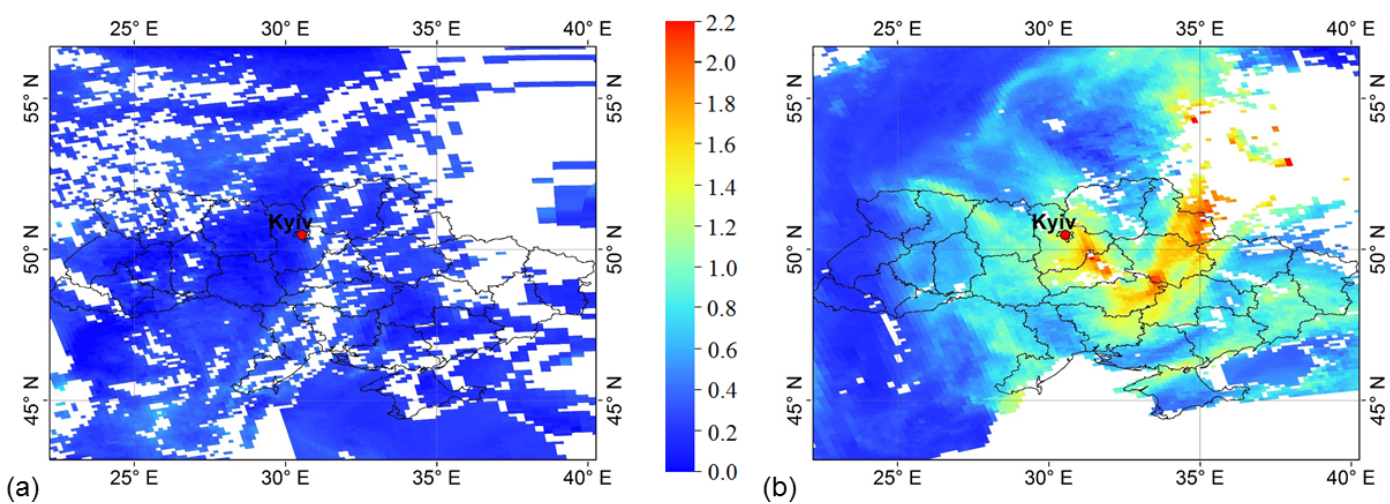

Figure 7. AOD $550 \mathrm{~nm}$ distribution from Aqua MODIS measurements on 17 July (a) and 15 August (b).

This AOD distribution map (Fig. 7b) resembles our air mass back trajectory calculations to Kyiv in the altitude range of $0.5-3 \mathrm{~km}$ for 15 August fairly well (see Fig. 3, Sect. 3.1). This indicates that the MODIS algorithm interprets aerosol over Kyiv in the same manner as AERONET. However, MODIS underestimates low AOD values and overestimates high AOD values in comparison with AERONET. Figure $7 \mathrm{~b}$ also highlights the importance of the availability of satellite observations for estimating air pollution over larger and remote regions, which cannot be deduced from a single site's ground-based measurements, as it is the case in Ukraine.

\subsubsection{Estimations of aerosol pollution using CALIOP data}

We calculated linear regression parameters of AOD measurements from MODIS (550 nm) and CALIOP (532 nm) for more than 3690 points of collocated measurements during 1 June-31 August 2010. We derived linear equation between CALIOP $\mathrm{AOD}_{\mathrm{cal}}$ and Aqua MODIS AOD $\mathrm{Dyd}_{\text {as }}$ follows: $\mathrm{AOD}_{\text {cal }}=(0.06 \pm 0.003)+(0.68 \pm 0.015) \times \mathrm{AOD}_{\text {myd }}$. A Pearson's correlation coefficient of $R=0.59$ indicated rather close relations between AOD from CALIOP and MODIS measurements. CALIOP and MODIS measured similarly at $\mathrm{AOD}=0.2$, although CALIOP overestimated lower and underestimated higher AOD values relative to MODIS. Thus, CALIOP underestimated AOD for the majority of the compared data over Ukraine in summer 2010. Also, the standard deviation from the regression line $(\mathrm{SD}=0.15)$ pointed to considerable discrepancies between the two satellites datasets. This means that the application of MODIS and AERONET data for the territory of Ukraine in summer 2010 is likely more reasonable to apply. Observed discrepancies between MODIS and CALIOP data can be explained by different independent measurements techniques, algorithms, and uncertainties of CALIOP daytime measurements. In this paper we do not analyze peculiarities of MODIS and CALIOP data and reasons of their discrepancies, as more detailed analysis can be found in Kittaka et al. (2011) and Rede- mann et al. (2012). Taking also into account uncertainties of both day- and nighttime CALIOP measurements, the instrument's AOD reasonably captures air pollution from wildfire aerosol. Most CALIOP data were obtained during night and have a higher fidelity than the daytime measurements (Omar et al., 2013). At this time CALIOP is the only instrument that provides data on nocturnal pollution of the atmosphere by aerosol. Due to its sparse coverage over investigated regions, the data product can be used only to roughly estimate severeness of pollution over longer periods. This is well illustrated in Fig. 8, showing all day- and nighttime AOD measurements during a 16-day period from 1 from 16 June (a) and from 4 to 19 August (b) 2010 that corresponds to the repeating cycle of the instrument. Ground tracks oriented from northeast to southwest correspond to nocturnal measurements and those oriented from southeast to northwest correspond to daytime measurements.

The CALIOP-measured AOD $532 \mathrm{~nm}$ over Ukraine and surrounding territories ranged approximately from 0 to 0.7 (Figs. 8a, S36a, b) during the first part of the summer 2010 (1 June-18 July), when number and brightness temperature of fires were still low (Fig. 2a-e). CALIOP confirms that on 19 July the aerosol content in the atmosphere increased, corresponding to the wildfire activities (Supplement Fig. S36c). During 4-19 August (Fig. 8b) a distinct pattern of aerosol pollution was observed, except the western part of Ukraine. In particular, during 9-18 August AOD values regionally exceeded 1 and reached a value of 2 at certain locations. This is in good agreement with MODIS observations on 15 August as shown in Fig. 7b. During those days weather conditions were stable and did not change much. For both instruments high AOD values (greater than 1.2) are seen over central and eastern Ukraine.

We also analyzed vertical distributions of aerosol extinction at $532 \mathrm{~nm}$ (Figs. 9, S37-S94). We compiled analyzed profiles for the cases with high AOD $532 \mathrm{~nm}$. This selection leads to 58 profiles for 11 tracks for the period 7-18 August 2010. The corresponding AOD $532 \mathrm{~nm}$ ranged from 0.44 (on 13 August 11:00:06) to 2.93 (on 18 August 00:08:26). 

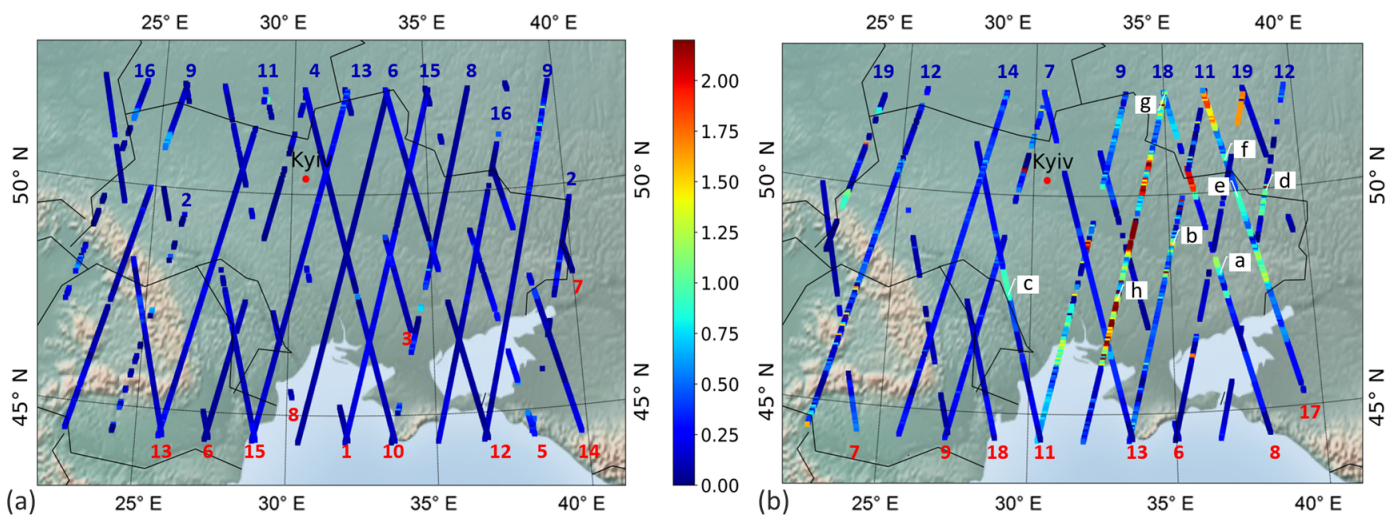

Figure 8. AOD $532 \mathrm{~nm}$ distribution over Ukraine from CALIOP measurements during 16-day periods from 1 to 16 June (a) and from 4 to 19 August (b) 2010. Red numbers at the bottom of the map indicate dates of each daytime track running to northwest and blue numbers at the top of the map indicate the date of each nocturnal track running to southwest. Labels a-h in Fig. 8b indicate the location of profiles, which are further analyzed and shown in Fig. 9.

Among selected profiles, 37 profiles on 7 ground tracks were nocturnal, and 21 profiles on 4 tracks were measured during daytime. The profiles reveal that aerosol ranged from about $40 \mathrm{~m}$ to mostly $5 \mathrm{~km}$ altitude. The vertical distributions varied significantly during both day- and nighttime. According to the peculiarities of aerosol vertical distribution, we identified three types of profiles. (1) Type 1 consists of profiles showing at least a single aerosol layer of some hundred meters thickness, located at about $1 \mathrm{~km}$ altitude or higher. (2) Type 2 consists of profiles showing a decrease of extinction coefficients with altitude, with a maximum extinction coefficient located near the surface. (3) Type 3 is characterized by relatively high extinction values over comparably large altitude ranges, spanning several kilometers without showing distinct maxima. Figure 9 depicts corresponding profiles, selected for those cases when the above-mentioned features are well pronounced. All other cases are shown in the Supplement Figs. S37-S94.

The aerosol extinction profile shown in Fig. 9a (location labeled "a" in Fig. 8b) represents the vertical distribution of particle concentration at the daytime CALIOP track in 8 August 2010, which crossed the southeast of Ukraine (see Fig. 8 b). AOD $532 \mathrm{~nm}$ at that point was 0.84 . At that location almost all aerosol concentrated in a narrow layer at an altitude of around $3.5 \mathrm{~km}$ (Type 1 profile). Shown in the Supplement Fig. S40 reveals a similar aerosol profile, which was measured few seconds earlier in a distance of $70 \mathrm{~km}$ from the site labeled "a" in Fig. 8b.

An extinction profile of Type 1 shown in Fig. 9b was observed at a segment of a CALIOP midnight track on $11 \mathrm{Au}-$ gust. Aerosol at this location labeled "b" in Fig. 8b was distributed at different altitudes from the surface to approximately $5 \mathrm{~km}$. There was only a thin layer showing a maximum extinction at $4.3 \mathrm{~km}$ altitude. In addition, a considerable amount of aerosol was observed near the surface. The chosen track segment was located about $210-250 \mathrm{~km}$ westward from the daytime track segment of 8 August.

The daytime CALIOP track on 11 August crossed the western region of Ukraine. The peak aerosol load in terms of AOD $532 \mathrm{~nm}$ was observed in the southwest region of Ukraine, with values around 0.9 (location labeled "c" in Fig. 8b). The measured aerosol extinction profile is of Type 2 , showing a maximum at $300-350 \mathrm{~m}$ altitude and gradually decreases above, up to $5 \mathrm{~km}$ altitude (Fig. 9c).

CALIOP's nocturnal track on 12 August ran over the east of Ukraine, where the highest AOD $532 \mathrm{~nm}$ of about 1.0 was found (location labeled "d" in Fig. 8b). Over a track segment of about $80 \mathrm{~km}$ length, most of the aerosol concentrated below $2 \mathrm{~km}$ altitude, with a maximum extinction coefficient at approximately $280 \mathrm{~m}$. Another less dense aerosol layer was observed between 3 and $4.5 \mathrm{~km}$ altitude (Fig. 9d). The profile can also be identified as Type 2 .

Five days later, on 17 August, the instrument was measuring over the same region during daytime (locations "e" and " $\mathrm{f}$ ", Fig. 8b). On this day, the aerosol distribution was much more variable than during days before. Figure 8e and f show two consecutively measured profiles with $15 \mathrm{~s}$ time difference that corresponded to approximately $100 \mathrm{~km}$ distance between appropriate points. The maximum extinction coefficient of the first profile (Type 2, Fig. 9e) was located at about $220 \mathrm{~m}$ and was gradually decreasing with altitude. On the other profile (Type 3, Fig. 9f) the maximum extinction coefficient was found significantly higher, at approximately $1 \mathrm{~km}$ altitude. Below, the extinction coefficient profile indicates practically clean air with values not exceeding $0.3 \mathrm{~km}^{-1}$. In the two measurements, the vertical extent of aerosol is approximately similar (at about $3 \mathrm{~km}$ ). Also, the AODs of both profiles do not differ much and range from 0.92 to 1.0 .

On 18 August, the day when the weather situation significantly changed, the profiles of extinction coefficient at 

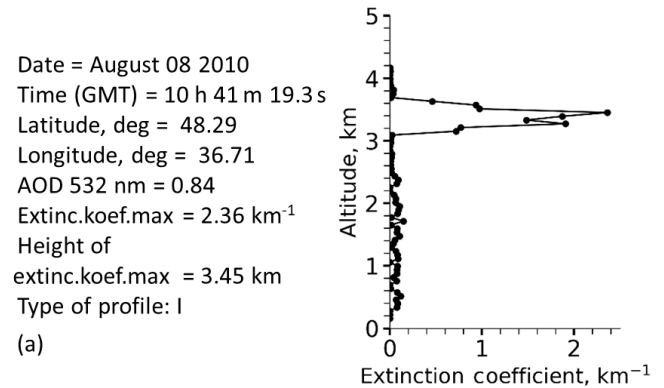

Date $=$ August 112010

Time (GMT) $=00 \mathrm{~h} 2 \mathrm{~m} 28.1 \mathrm{~s}$ Latitude, deg $=48.81$ Longitude, deg $=35.08$ AOD $532 \mathrm{~nm}=1.58$ Extinc. koef.max $=1.54 \mathrm{~km}^{-1}$ Height of

extinc. koef. $\max =4.29$

Type of profile: I

(b)
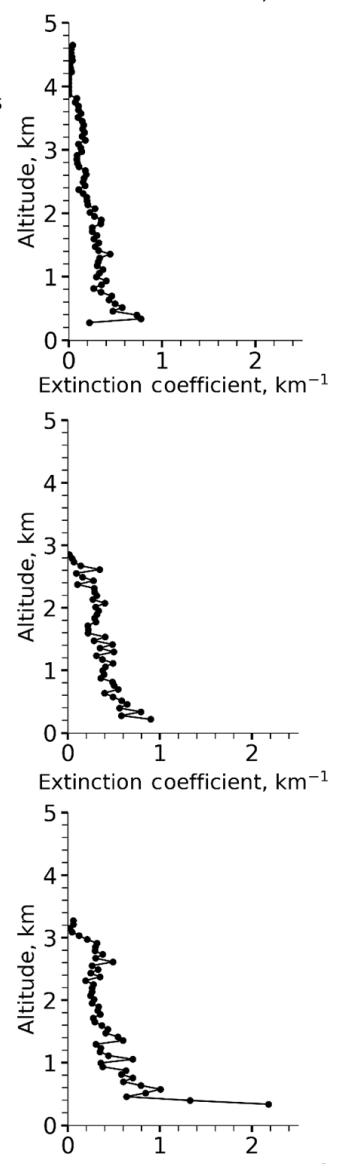

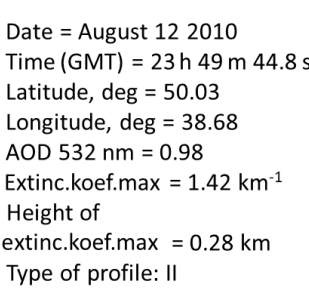

(d)

Date = August 172010

Time $(\mathrm{GMT})=10 \mathrm{~h} 35 \mathrm{~m} 46.3 \mathrm{~s}$ Latitude, deg $=50.80$ Longitude, deg $=37.22$ AOD $532 \mathrm{~nm}=1.00$

Extinc.koef.max $=1.12 \mathrm{~km}^{-1}$ Height of extinc.koef.max $=0.94 \mathrm{~km}$ Type of profile: III (f)

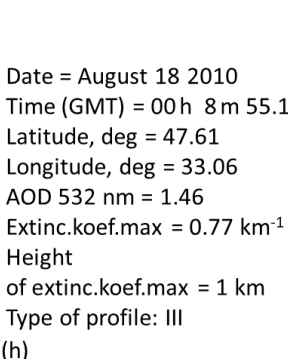
(h)
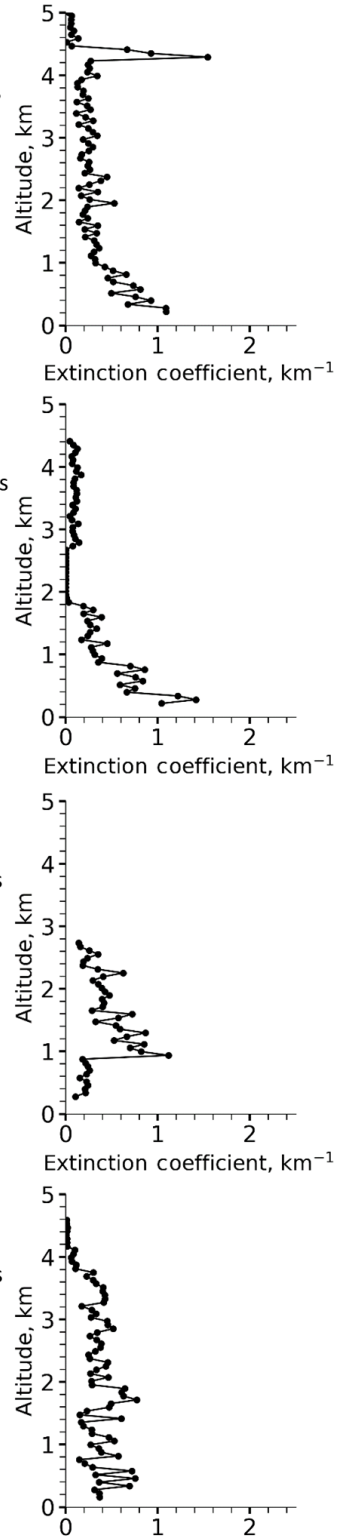

Extinction coefficient, $\mathrm{km}^{-1}$

Figure 9. Selected vertical profiles of aerosol extinction coefficient from CALIOP measurements over Ukraine during active fires period in summer 2010. The location of profiles is shown in Fig. $8 \mathrm{~b}$ with corresponding a-h labels.

midnight showed a much higher variability (Fig. 9g, h, locations labeled "g" and "h" in Fig. 8b). The track was located westward relative to the daytime track on 17 August. The analyzed segment of CALIOP's nocturnal track had a length of about $250 \mathrm{~km}$ and was located southwest of the site labeled "g" in Fig. 8b (see the Supplement Figs. S85S89). The aerosol layer at location "g" in Fig. 8b extended up to about $3.5 \mathrm{~km}$ (profile Type 2, Fig. 9g). Further along the track up to the coast of the Black Sea aerosol vertical distribution changed into profile Type 3 (Fig. 8b, label "h" and Fig. 9h). At certain locations relatively high extinction coefficients were found from near the surface up to about $4.5 \mathrm{~km}$
(Fig. 9h), but at few other locations aerosol concentrated at several relatively thin layers at different altitudes (Supplement Figs. S90-S94).

In conclusion, our CALIOP profile measurements are well reflecting the large diversity of aerosol layers in the region and period under investigation. Although the maximum extinction coefficient was approximately $1 \mathrm{~km}^{-1}$ in most analyzed profiles, we noted a large spread from some tenth to $8.5 \mathrm{~km}^{-1}$ (Supplement Fig. S86) in certain very dense plumes. The advantage of analyzing aerosol vertical distributions allows a better evaluation of air pollution cases, for example by determining altitudes of highest aerosol content 
- information that cannot be concluded from vertically integrated aerosol properties, like the AOD.

\section{Conclusions}

In this study we analyzed the influence of wildfires on aerosol dynamics over the ETR and Eastern Europe, in particular on air pollution conditions over Ukraine during an extreme heat wave event in summer 2010. Specific weather conditions with high air temperature and low relative humidity (Witte et al., 2011) formed under anticyclonic circulation, which caused air stagnation and accumulation of contaminants. Moreover, those weather conditions were favorable for wildfires to evolve.

To reveal the connection between wildfires and aerosol properties over the ETR and Eastern Europe, we analyzed fire locations and their brightness temperature from MODIS measurements for the period 1 June-31 August 2010. We demonstrated that the fire activities increased from mid-July mostly over the ETR, Ukraine, and Moldova. The largest number and brightness temperature of fires were observed during 26 July-18 August. To consider the impact of those wildfires on aerosol dynamics over the ETR and Eastern Europe, we chose 10 AERONET sites in that region and computed HYSPLIT back trajectories to those sites. Our analysis of back trajectories showed that the observed AOD maximum over each of the considered sites was formed as a result of air transport from the areas of active wildfires. AOD maxima at the Belsk site (central Poland), Moldova (Chisinau, Moldova), and Cluj-Napoca and Eforie (Romania) were caused mainly by fires in Ukraine and Moldova in July. AOD maxima over other AERONET sites were caused by aerosol from fires in the ETR. We also provided detailed analysis of aerosol dynamics over Ukraine. Despite the available studies of aerosol dynamics over Ukraine (Bovchaliuk et al., 2013; Danylevsky et al., 2011a, b; Milinevsky et al., 2014), we focused on the evaluation of the impact of the wildfires in summer 2010 on the tropospheric aerosol load, which has not been done before.

The ground-based AERONET measurements over the Kyiv site showed that for the entire observational period (from April 2008 to November 2016) the highest air pollution caused by aerosol was recorded in August 2010. The average AOD $500 \mathrm{~nm}$ in August 2010 exceeded multiannual monthly mean (2008-2016, excluding 2010) by a factor of 2.2. We showed that during June 2010 the wildfires were not affecting AOD over the Kyiv site. Both aerosol content and properties were determined mostly by local sources and air transport from Western Europe. In contrast, from July to mid-August, the AOD increase over the Kyiv site was caused by air transport from the wildfire regions. The influence of fires resulted in an increased relative content of the fine mode in particles size distribution, accompanied by an increase of their effective radius (Fig. 6a, b). Occasionally the coarse mode also resulted in both an increase of $\mathrm{AOD}$ and a decrease of $\mathrm{AE}$ for days, exhibiting a higher number of fires. We explained the predominant impact of fine-mode aerosol on the AOD increase by its longer lifetime in comparison with the coarse mode.

We also analyzed the impact of wildfires on aerosol spectral SSA at the Kyiv site during three different periods: (1) 126 June, when the number of fires and their brightness temperature were low; (2) 18 July-14 August, when the number of fires significantly increased; and (3) 15-17 August, when the highest AOD values were observed. Smaller SSA values during 18 July-14 August were likely caused by an increase of the soot content in the air, transported from the wildfires. SSA and RI spectral characteristics changed during that period, increasing the absorption capacity of aerosol, especially in longer wavelengths. During 15-17 August we observed relatively large SSA values. According to Eck et al. (2009), the observed increase of SSA can explained by an increased particle size caused by wildfires, which in turn increased the total reflectance in the atmospheric column. Microphysical properties of aerosol over Kyiv under the influence of intense fires correspond well with general characteristics of biomass burning and polluted continental aerosol, as derived from AERONET sun photometer measurements (Dubovik et al., 2002; Omar et al., 2005, 2009).

Our comparison of AOD measurements from MODIS and AERONET showed strong functional relations between the datasets with Pearson's correlation coefficients of 0.96 for Aqua MODIS and 0.98 for Terra MODIS. AOD measured by MODIS is therefore well captured for the entire Ukraine. Both Aqua MODIS and Terra MODIS represent the aerosol content in the atmosphere over Ukraine for summer 2010 within measurement uncertainties of around 0.15 standard deviation of AOD. The spatial distribution of MODIS AOD revealed that the wildfires of summer 2010 significantly impacted the eastern, central, and southern parts of Ukraine. The AOD at $550 \mathrm{~nm}$ reached values of 2 (and more) at certain sites, especially in the middle of August.

Our comparison of AOD between CALIOP and MODIS revealed that the correlation coefficient was not larger than 0.6 between datasets. Over Ukraine CALIOP mainly underestimated the AOD in comparison with MODIS for the entire summer 2010. This can be explained by findings of Kittaka et al. (2011), who showed that the CALIOP algorithm likely ignores tenuous aerosol, causing an underestimation of AOD in comparison with MODIS. They also found that the aerosol layer's base height can be detected at higher altitudes, leading to an AOD underestimation.

Despite the uncertainties and sparse availability of CALIOP measurements for the time and regions we analyzed, spatial distributions of AOD from CALIOP measurements over Ukraine corresponded well with those from MODIS, in accordance with Kittaka et al. (2011). Another advantage is that CALIOP also measures at nighttime. According to CALIOP observations, the day- and nighttime 
AOD did not differ distinctly from each other during the analyzed period. This also corresponds to the global-scale analysis of Kittaka et al. (2011).

We also analyzed aerosol profiles provided by CALIOP, which is the only source of aerosol vertical distribution for our study. We found that the aerosol was distributed at altitudes from about $40 \mathrm{~m}$ to $5 \mathrm{~km}$ and the extinction coefficient mostly ranged from a few tens to $1 \mathrm{~km}^{-1}$, although sometimes it exceeded $8 \mathrm{~km}^{-1}$ in very dense plumes.

Summarizing, in this study we provided evidence of reasonable agreement between different types of aerosol measurements over Ukraine for the unique period in summer 2010. Further studies are needed to investigate the influence of the different fire regions on the air quality over Ukraine, which in our study could not be resolved well from the partly sparse coincidence of the datasets that are available until now. Not only other satellite instruments can be taken into account to further improve the accuracy of pollution levels analysis. The expansion of the ground-based sun photometer network and in particular the availability of in situ observations would help, for instance, to resolve the large spatial gradients of the pollution levels that have been found over relatively densely populated areas.

Data availability. The AERONET dataset of AOD, AE, aerosol size distribution, SSA, and RI are available at https://aeronet. gsfc.nasa.gov. MODIS (Terra and Aqua) AOD dataset is available at https://modis-images.gsfc.nasa.gov/MOD04_L2/index. html. Dataset of spatiotemporal fire distribution is available at ftp: //fuoco.geog.umd.edu/. The username is "fire" and the password is "burnt". CALIOP datasets of Level 2 Cloud and Aerosol Layer and Profile products versions 3.01 and 3.02 are available at https:// eosweb.larc.nasa.gov/project/calipso/calipso_table. The HYSPLIT model is available at https://ready.arl.noaa.gov/HYSPLIT.php; results of HYSPLIT simulations presented in this paper are available upon request from the authors.

Supplement. The supplement related to this article is available online at: https://doi.org/10.5194/amt-11-2101-2018-supplement.

Competing interests. The authors declare that they have no conflict of interest.

Acknowledgements. This publication includes results of the research that is performed in Astronomical observatory of Taras Shevchenko National university of Kyiv, Ukraine, project 16BF023-01, funded by the Ministry of Education and Science of Ukraine. Parts of the research have been funded by the University and State of Bremen. We thank PI investigators and their staff for establishing and maintaining the Minsk, Moscow, Toravere, Belsk, Chisinau, Cluj-Napoca, Bucharest, Eforie, Kyiv, and Sevastopol AERONET sites used in this investigation.
The article processing charges for this open-access publication were covered by the University of Bremen.

Edited by: Oleg Dubovik

Reviewed by: four anonymous referees

\section{References}

Anderson, T. L., Charlson, R. J., Winker, D. M., Ogren, J. A., and Holmén, K.: Mesoscale Variations of Tropospheric Aerosols, J. Atmos. Sci., 60, 119-136, https://doi.org/10.1175/15200469(2003)060<0119:MVOTA>2.0.CO;2, 2003.

Barnaba, F., Angelini, F., Curci, G., and Gobbi, G. P.: An important fingerprint of wildfires on the European aerosol load, Atmos. Chem. Phys., 11, 10487-10501, https://doi.org/10.5194/acp-1110487-2011, 2011.

Barriopedro, D., Fischer, E. M., Luterbacher, J., Trigo, R. M., and García-Herrera, R.: The Hot Summer of 2010: Redrawing the Temperature Record Map of Europe, Science, 332, 220-224, https://doi.org/10.1126/science.1201224, 2011.

Bovchaliuk, A., Milinevsky, G., Danylevsky, V., Goloub, P., Dubovik, O., Holdak, A., Ducos, F., and Sosonkin, M.: Variability of aerosol properties over Eastern Europe observed from ground and satellites in the period from 2003 to 2011, Atmos. Chem. Phys., 13, 6587-6602, https://doi.org/10.5194/acp13-6587-2013, 2013.

Bowman, K. P., Lin, J. C., Stohl, A., Draxler, R., Konopka, P., Andrews, A., and Brunner, D.: Input Data Requirements for Lagrangian Trajectory Models, B. Am. Meteorol. Soc., 94, 10511058, https://doi.org/10.1175/BAMS-D-12-00076.1, 2013.

Bréon, F.-M., Vermeulen, A., and Descloitres, J.: An evaluation of satellite aerosol products against sunphotometer measurements, Remote Sens. Environ., 115, 3102-3111, https://doi.org/10.1016/j.rse.2011.06.017, 2011.

Chubarova, N., Nezval', Ye., Sviridenkov, I., Smirnov, A., and Slutsker, I.: Smoke aerosol and its radiative effects during extreme fire event over Central Russia in summer 2010, Atmos. Meas. Tech., 5, 557-568, https://doi.org/10.5194/amt-5557-2012, 2012.

Crutzen, P. J. and Andreae, M. O.: Biomass Burning in the Tropics: Impact on Atmospheric Chemistry and Biogeochemical Cycles, Science, 250, 1669-1678, https://doi.org/10.1126/science.250.4988.1669, 1990.

Danylevsky, V., Ivchenko, V., Milinevsky, G., Grytsai, A., Sosonkin, M., Goloub, P., Li, Z., and Dubovik, O.: Aerosol layer properties over Kyiv from AERONET/PHOTONS sunphotometer measurements during 2008-2009, Int. J. Remote Sens., 32, 657-669, https://doi.org/10.1080/01431161.2010.517798, 2011a.

Danylevsky, V., Ivchenko, V., Milinevsky, G., Sosonkin, M., Goloub, P., Li, Z., and Dubovik, O.: Atmosphere Aerosol Properties Measured with AERONET/PHOTONS Sun-Photometer over Kyiv During 2008-2009, Springer Netherlands, the Dordrecht, 285-294, https://doi.org/10.1007/978-90-481-96180_32, 2011b.

Davies, D. K., Ilavajhala, S., Wong, M. M., and Justice, C. O.: Fire Information for Resource Management System: Archiving and 
Distributing MODIS Active Fire Data, IEEE T. Geosci. Remote, 47, 72-79, https://doi.org/10.1109/TGRS.2008.2002076, 2009.

Demirtaş, M.: High Impact Heat Waves Over The EuroMediterranean Region And Turkey - In Concert With Atmospheric Blocking And Large Dynamical And Physical Anomalies, Anadolu Üniversitesi Bilim Ve Teknoloji Dergisi A - Uygulamalı Bilimler ve Mühendislik, 18, 97-114, https://doi.org/10.18038/aubtda.300426, 2017.

Dole, R., Hoerling, M., Perlwitz, J., Eischeid, J., Pegion, P., Zhang, T., Quan, X.-W., Xu, T., and Murray, D.: Was there a basis for anticipating the 2010 Russian heat wave?, Geophys. Res. Lett., 38, L06702, https://doi.org/10.1029/2010GL046582, 2011.

Draxler, R. R. and Hess, G. D.: An Overview of the HYSPLIT_4 modeling system for trajectories, dispersion and deposition, Aust. Meteorol. Mag., 47, 295-308, 1998.

Dubovik, O. and King, M. D.: A flexible inversion algorithm for retrieval of aerosol optical properties from Sun and sky radiance measurements, J. Geophys. Res.-Atmos., 105, 20673-20696, https://doi.org/10.1029/2000JD900282, 2000.

Dubovik, O., Smirnov, A., Holben, B. N., King, M. D., Kaufman, Y. J., Eck, T. F., and Slutsker, I.: Accuracy assessments of aerosol optical properties retrieved from Aerosol Robotic Network (AERONET) Sun and sky radiance measurements, J. Geophys. Res.-Atmos., 105, 9791-9806, https://doi.org/10.1029/2000JD900040, 2000.

Dubovik, O., Holben, B., Eck, T. F., Smirnov, A., Kaufman, Y. J., King, M. D., Tanré, D., and Slutsker, I.: Variability of Absorption and Optical Properties of Key Aerosol Types Observed in Worldwide Locations, J. Atmos. Sci., 59, 590-608, https://doi.org/10.1175/15200469(2002)059<0590:VOAAOP>2.0.CO;2, 2002.

Eck, T. F., Holben, B. N., Reid, J. S., Dubovik, O., Smirnov, A., O’Neill, N. T., Slutsker, I., and Kinne, S.: Wavelength dependence of the optical depth of biomass burning, urban, and desert dust aerosols, J. Geophys. Res.-Atmos., 104, 31333 31349, https://doi.org/10.1029/1999JD900923, 1999.

Eck, T. F., Holben, B. N., Reid, J. S., Sinyuk, A., Hyer, E. J., O'Neill, N. T., Shaw, G. E., Vande Castle, J. R., Chapin, F. S., Dubovik, O., Smirnov, A., Vermote, E., Schafer, J. S., Giles, D., Slutsker, I., Sorokine, M., and Newcomb, W. W.: Optical properties of boreal region biomass burning aerosols in central Alaska and seasonal variation of aerosol optical depth at an Arctic coastal site, J. Geophys. Res.-Atmos., 114, D11201, https://doi.org/10.1029/2008JD010870, 2009.

Holben, B., Eck, T., Slutsker, I., Tanré, D., Buis, J., Setzer, A., Vermote, E., Reagan, J., Kaufman, Y., Nakajima, T., Lavenu, F., Jankowiak, I., and Smirnov, A.: AERONET - A Federated Instrument Network and Data Archive for Aerosol Characterization, Remote Sens. Environ., 66, 1-16, https://doi.org/10.1016/S0034-4257(98)00031-5, 1998.

Holben, B. N., Tanré, D., Smirnov, A., Eck, T. F., Slutsker, I., Abuhassan, N., Newcomb, W. W., Schafer, J. S., Chatenet, B., Lavenu, F., Kaufman, Y. J., Castle, J. V., Setzer, A., Markham, B., Clark, D., Frouin, R., Halthore, R., Karneli, A., O’Neill, N. T., Pietras, C., Pinker, R. T., Voss, K., and Zibordi, G.: An emerging ground-based aerosol climatology: Aerosol optical depth from AERONET, J. Geophys. Res.-Atmos., 106, 12067-12097, https://doi.org/10.1029/2001JD900014, 2001.
Hunt, W. H., Winker, D. M., Vaughan, M. A., Powell, K. A., Lucker, P. L., and Weimer, C.: CALIPSO Lidar Description and Performance Assessment, J. Atmos. Ocean. Tech., 26, 1214-1228, https://doi.org/10.1175/2009JTECHA1223.1, 2009.

Ichoku, C., Chu, D. A., Mattoo, S., Kaufman, Y. J., Remer, L. A., Tanré, D., Slutsker, I., and Holben, B. N.: A spatiotemporal approach for global validation and analysis of MODIS aerosol products, Geophys. Res. Lett., 29, MOD1-1-MOD1-4, https://doi.org/10.1029/2001GL013206, 2002.

Justice, C., Giglio, L., Korontzi, S., Owens, J., Morisette, J., Roy, D., Descloitres, J., Alleaume, S., Petitcolin, F., and Kaufman, Y.: The MODIS fire products, Remote Sens. Environ., 83, 244-262, https://doi.org/10.1016/S0034-4257(02)00076-7, 2002.

Justice, C. O., Giglio, L., Roy, D., Boschetti, L., Csiszar, I., Davies, D., Korontzi, S., Schroeder, W., O’Neal, K., and Morisette, J.: MODIS-Derived Global Fire Products, Springer New York, New York, NY, 661-679, https://doi.org/10.1007/978-1-4419-67497_29, 2011.

Kittaka, C., Winker, D. M., Vaughan, M. A., Omar, A., and Remer, L. A.: Intercomparison of column aerosol optical depths from CALIPSO and MODIS-Aqua, Atmos. Meas. Tech., 4, 131-141, https://doi.org/10.5194/amt-4-131-2011, 2011.

Konovalov, I. B., Beekmann, M., Kuznetsova, I. N., Yurova, A., and Zvyagintsev, A. M.: Atmospheric impacts of the 2010 Russian wildfires: integrating modelling and measurements of an extreme air pollution episode in the Moscow region, Atmos. Chem. Phys., 11, 10031-10056, https://doi.org/10.5194/acp-11-100312011, 2011.

Levy, R. C., Remer, L. A., and Dubovik, O.: Global aerosol optical properties and application to Moderate Resolution Imaging Spectroradiometer aerosol retrieval over land, J. Geophys. Res.Atmos., 112, D13210, https://doi.org/10.1029/2006JD007815, 2007.

Levy, R. C., Remer, L. A., Tanré, D., Mattoo, S., and Kaufman, Y. J.: Algorithm for remote sensing of tropospheric aerosol over dark targets from MODIS: Collections 005 and 051: Revision 2, MODIS Algorithm Theoretical Basis Document, 2009. This document is also accessible online: https://modis-images.gsfc.nasa. gov/_docs/ATBD_MOD04_C005_rev2.pdf, 2009.

Levy, R. C., Remer, L. A., Kleidman, R. G., Mattoo, S., Ichoku, C., Kahn, R., and Eck, T. F.: Global evaluation of the Collection 5 MODIS dark-target aerosol products over land, Atmos. Chem. Phys., 10, 10399-10420, https://doi.org/10.5194/acp-10-103992010, 2010.

Levy, R. C., Mattoo, S., Munchak, L. A., Remer, L. A., Sayer, A. M., Patadia, F., and Hsu, N. C.: The Collection 6 MODIS aerosol products over land and ocean, Atmos. Meas. Tech., 6, 29893034, https://doi.org/10.5194/amt-6-2989-2013, 2013.

Milinevsky, G., Danylevsky, V., Bovchaliuk, V., Bovchaliuk, A., Goloub, Ph., Dubovik, O., Kabashnikov, V., Chaikovsky, A., Miatselskaya, N., Mishchenko, M., and Sosonkin, M.: Aerosol seasonal variations over urban-industrial regions in Ukraine according to AERONET and POLDER measurements, Atmos. Meas Tech., 7, 1459-1474, https://doi.org/10.5194/amt-7-1459-2014, 2014.

NASA: AERONET Level 2.0 (Quality Assured) Aerosol Optical Depth (AOD), available at: https://aeronet.gsfc.nasa.gov, last access: 10 April 2017 
NASA: MODIS (Terra and Aqua) AOD, available at: https: //modis-images.gsfc.nasa.gov/MOD04_L2/index.html, Level 2 Collection 005 and 051 Optical_Depth_Land_And_Ocean, last access: 10 April 2017.

NASA: MODIS Active Fire Product, Spatiotemporal fire distribution, available at: ftp://fuoco.geog.umd.edu/, ftp server is maintained by the University of Maryland, last access: 10 April 2017.

NASA: Level 2 Cloud and Aerosol Layer and Profile products, CALIOP datasets of Level 2 Cloud and Aerosol Layer and Profile products versions 3.01 and 3.02, available at: https://eosweb. larc.nasa.gov/project/calipso/calipso_table, last access: 10 April 2017.

NOAA: HYSPLIT model, available at: https://ready.arl.noaa.gov/ HYSPLIT.php, last access: 10 April 2017.

Omar, A. H., Won, J.-G., Winker, D. M., Yoon, S.-C., Dubovik, O., and McCormick, M. P.: Development of global aerosol models using cluster analysis of Aerosol Robotic Network (AERONET) measurements, J. Geophys. Res.-Atmos., 110, D10S14, https://doi.org/10.1029/2004JD004874, 2005.

Omar, A. H., Winker, D. M., Vaughan, M. A., Hu, Y., Trepte, C. R., Ferrare, R. A., Lee, K.-P., Hostetler, C. A., Kittaka, C., Rogers, R. R., Kuehn, R. E., and Liu, Z.: The CALIPSO Automated Aerosol Classification and Lidar Ratio Selection Algorithm, J. Atmos. Ocean. Tech., 26, 1994-2014, https://doi.org/10.1175/2009JTECHA1231.1, 2009.

Omar, A. H., Winker, D. M., Tackett, J. L., Giles, D. M., Kar, J., Liu, Z., Vaughan, M. A., Powell, K. A., and Trepte, C. R.: CALIOP and AERONET aerosol optical depth comparisons: One size fits none, J. Geophys. Res.-Atmos., 118, 4748-4766, https://doi.org/10.1002/jgrd.50330, 2013.

O’Neill, N. T., Eck, T. F., Smirnov, A., Holben, B. N., and Thulasiraman, S.: Spectral discrimination of coarse and fine mode optical depth, J. Geophys. Res.-Atmos., 108, 4559, https://doi.org/10.1029/2002JD002975, 2003.

Péré, J. C., Bessagnet, B., Mallet, M., Waquet, F., Chiapello, I., Minvielle, F., Pont, V., and Menut, L.: Direct radiative effect of the Russian wildfires and its impact on air temperature and atmospheric dynamics during August 2010, Atmos. Chem. Phys., 14, 1999-2013, https://doi.org/10.5194/acp-14-1999-2014, 2014.

Redemann, J., Vaughan, M. A., Zhang, Q., Shinozuka, Y., Russell, P. B., Livingston, J. M., Kacenelenbogen, M., and Remer, L. A.: The comparison of MODIS-Aqua (C5) and CALIOP (V2 \& V3) aerosol optical depth, Atmos. Chem. Phys., 12, 3025-3043, https://doi.org/10.5194/acp-12-3025-2012, 2012.

Remer, L. A., Kaufman, Y. J., Tanré, D., Mattoo, S., Chu, D. A., Martins, J. V., Li, R.-R., Ichoku, C., Levy, R. C., Kleidman, R. G., Eck, T. F., Vermote, E., and Holben, B. N.: The MODIS Aerosol Algorithm, Products, and Validation, J. Atmos. Sci., 62, 947-973, https://doi.org/10.1175/JAS3385.1, 2005.

Remer, L. A., Kleidman, R. G., Levy, R. C., Kaufman, Y. J., Tanré, D., Mattoo, S., Martins, J. V., Ichoku, C., Koren, I., Yu, H., and Holben, B. N.: Global aerosol climatology from the MODIS satellite sensors, J. Geophys. Res.-Atmos., 113, D14S07, https://doi.org/10.1029/2007JD009661, 2008.
Schroeder, W., Prins, E., Giglio, L., Csiszar, I., Schmidt, C., Morisette, J., and Morton, D.: Validation of GOES and MODIS active fire detection products using ASTER and ETM+ data, Remote Sens. Environ., 112, 2711-2726, https://doi.org/10.1016/j.rse.2008.01.005, 2008.

Seiler, W. and Crutzen, P. J.: Estimates of gross and net fluxes of carbon between the biosphere and the atmosphere from biomass burning, Climatic Change, 2, 207-247, https://doi.org/10.1007/BF00137988, 1980.

Seinfeld, J. and Pandis, S.: Atmospheric Chemistry and Physics: From Air Pollution to Climate Change, A WileyInterscience publication, Wiley, https://books.google.de/books? id=tZEpAQAAMAAJ (last access: 9 April 2018), 2006.

Shevchenko, O., Lee, H., Snizhko, S., and Mayer, H.: Long-term analysis of heat waves in Ukraine, Int. J. Climatol., 34, 16421650, https://doi.org/10.1002/joc.3792, 2014.

Stohl, A.: Chapter 21 Computation, accuracy and applications of trajectories - a review and bibliography, Dev. Environm. Sci., 1, 615-654, https://doi.org/10.1016/S1474-8177(02)800249, 2002.

Vaughan, M. A., Powell, K. A., Winker, D. M., Hostetler, C. A., Kuehn, R. E., Hunt, W. H., Getzewich, B. J., Young, S. A., Liu, Z., and McGill, M. J.: Fully Automated Detection of Cloud and Aerosol Layers in the CALIPSO Lidar Measurements, J. Atmos. Ocean. Tech., 26, 2034-2050, https://doi.org/10.1175/2009JTECHA1228.1, 2009.

Winker, D. M., Pelon, J. R., and McCormick, M. P.: The CALIPSO mission: spaceborne lidar for observation of aerosols and clouds, Lidar Remote Sensing for Industry and Environment Monitoring III, Proc. SPIE, 4893, https://doi.org/10.1117/12.466539, 2003.

Winker, D. M., Vaughan, M. A., Omar, A., Hu, Y., Powell, K. A., Liu, Z., Hunt, W. H., and Young, S. A.: Overview of the CALIPSO Mission and CALIOP Data Processing Algorithms, J. Atmos. Ocean. Tech., 26, 2310-2323, https://doi.org/10.1175/2009JTECHA1281.1, 2009.

Winker, D. M., Pelon, J., Coakley, J. A., Ackerman, S. A., Charlson, R. J., Colarco, P. R., Flamant, P., Fu, Q., Hoff, R. M., Kittaka, C., Kubar, T. L., Treut, H. L., McCormick, M. P., Mégie, G., Poole, L., Powell, K., Trepte, C., Vaughan, M. A., and Wielicki, B. A.: The CALIPSO Mission: A Global 3D View of Aerosols and Clouds, B. Am. Meteorol. Soc., 91, 1211-1229, https://doi.org/10.1175/2010BAMS3009.1, 2010.

Witte, J. C., Douglass, A. R., da Silva, A., Torres, O., Levy, R., and Duncan, B. N.: NASA A-Train and Terra observations of the 2010 Russian wildfires, Atmos. Chem. Phys., 11, 9287-9301, https://doi.org/10.5194/acp-11-9287-2011, 2011.

Young, S. A., Vaughan, M. A., Kuehn, R. E., and Winker, D. M.: The Retrieval of Profiles of Particulate Extinction from Cloud-Aerosol Lidar and Infrared Pathfinder Satellite Observations (CALIPSO) Data: Uncertainty and Error Sensitivity Analyses, J. Atmos. Ocean. Tech., 30, 395-428, https://doi.org/10.1175/JTECH-D-12-00046.1, 2013. 